\title{
The Interaction Between Redox and Hypoxic Signalling Pathways in the Dynamic Oxygen Environment of Cancer Cells
}

\author{
Maneet Bhatia, Therese C. Karlenius, Giovanna Di Trapani \\ and Kathryn F. Tonissen
}

Additional information is available at the end of the chapter

http://dx.doi.org/10.5772/55185

\section{Introduction}

Oxygen is essential for the survival of all living beings. A balanced oxygen environment is required since both lower and higher than the required oxygen levels can be detrimental to the cells (Figure 1). The oxygen state of a tissue results from the relative contributions of oxygen consumption and delivery. Different organs in the body exist under different oxygen environments, depending on the location and function of the cells in an organ. Most healthy organs reside in 3-6\% oxygen [1] while conditions lower than $3 \%$ oxygen are described as hypoxia. Cells also survive in hypoxic environments during normal development [2]. However, hypoxia is mostly detrimental to the cells by disrupting the oxygen homeostasis.

Cancer cells are capable of surviving under hypoxic conditions by inducing the expression of metabolic enzymes required for anaerobic metabolism. To fulfill their oxygen and nutritional requirements, cancer cells can also induce the formation of blood vessels by a process called angiogenesis. A transcription factor called hypoxia inducible factor-1 (HIF-1) is responsible for induction of specific gene expression by binding to hypoxic response elements (HRE) present in the promoters of these target genes, which are essential for cells to survive under a low oxygen environment, as reviewed recently in [3]. When hypoxic tumor cells are reoxygenated due to angiogenesis, oxidative stress may occur. However, angiogenesis in tumors is aberrant due to sparse arteriolar supply [4], low vascular density [5], and inefficient orientation of microvessels [6]. This creates a scenario where cancer cells are in flux, where they cycle between hypoxia and the reoxygenated state. There are two dominant timescales that contribute to the cycling kinetics. One is of a faster frequency with a few cycles per hour and primarily arises from fluctuations in red blood cell flux [7]. The 
slower timescale varies from hours to days and is due to vascular remodeling [8]. This makes angiogenesis irregular with respect to both space and time, thereby leading to an unstable cancer environment that oscillates between low and high oxygen conditions. This cycling phenomenon is termed intermittent hypoxia or cycling hypoxia [9]. The involvement of reoxygenation phases in intermittent hypoxia suggests the possibility that redox enzymes, such as thioredoxin, may be upregulated in addition to the hypoxic enzymes.

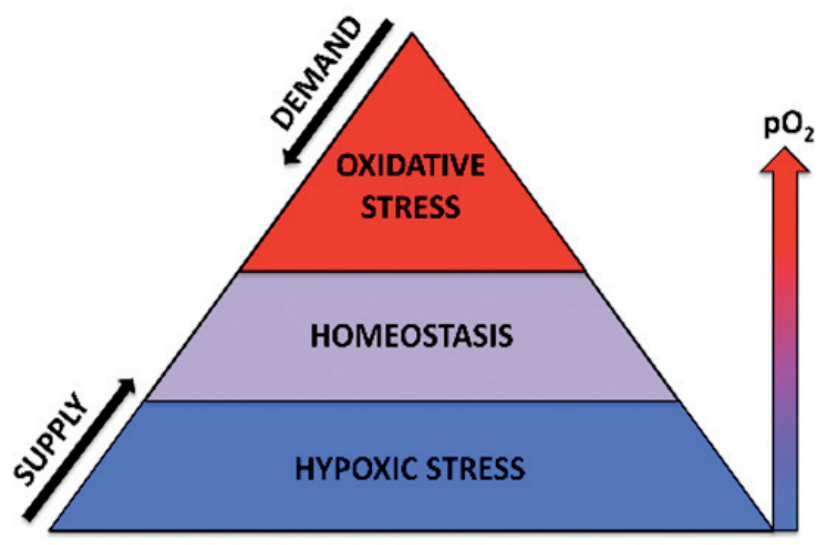

Figure 1. Oxygen homeostasis. Low cellular oxygen results in hypoxic stress causing cells to upregulate pathways involved in increasing the oxygen supply. On the other hand, higher oxygen levels result in oxidative stress and many antioxidants are induced in response, in order to reduce the available oxygen and prevent subsequent cellular damage.

\section{The thioredoxin system}

Cellular oxygen status is a key regulator of several important biological functions. To maintain the oxygen homeostasis, cells utilize antioxidant systems. An important antioxidant system that is present in all species and is conserved through evolution is the thioredoxin system. It comprises thioredoxin and thioredoxin reductase and catalyses oxidoreductase reactions through a dithiol-disulfide exchange mechanism [10]. Thioredoxin is a small $12 \mathrm{kDa}$ protein containing an active site motif of Cys-Gly-Pro-Cys. Reduced thioredoxin catalyses the reduction of disulphide bonds in other oxidised proteins and in the process itself becomes oxidised such that a disulphide bond forms between the two cysteine residues in its active site. Thioredoxin is then restored to a reduced state by thioredoxin reductase with the use of NADPH [10].

\subsection{Subcellular localisation and functions of thioredoxin}

Thioredoxin is found in the cytoplasm, in the nucleus and also in the extracellular environment and it has distinct functions in each location (Figure 2). The key function of the thioredoxin system is to maintain the redox balance of cells by either directly scavenging highly unstable and reactive molecules known as reactive oxygen species (ROS) [11] or by regulating the activity of several other important enzymes, such as peroxiredoxins [12] and 
methionine sulfoxide reductase (MSR) [13] that also maintain the cellular oxygen balance. Peroxiredoxins are a family of small $(22-27 \mathrm{kDa})$ peroxidases comprised of 6 isoforms. They use their - $\mathrm{SH}$ groups as reducing equivalents and act to reduce peroxides such as $\mathrm{H}_{2} \mathrm{O}_{2}$, organic hydroperoxides and peroxynitrite [12]. The oxidised form of peroxiredoxins can then be recycled back to their active reduced form through the action of an electron donor, which for peroxiredoxins 1-5 is thioredoxin. The MSR family consists of MSRA and MSRB antioxidant proteins and provides an indirect defense against ROS. Methionine residues in several proteins become oxidised by ROS to Met-S-O and Met-R-O, epimers of methionine sulfoxide (Met-O). This can render the proteins non-functional. MSRA and MSRB can restore the functionality of proteins by reducing the Met-S-O and Met-R-O bound proteins respectively [14]. During this process the MSR proteins become oxidised, but are reduced to their active form by thioredoxin. Thioredoxin also directly interacts with the apoptotic pathway by binding to apoptosis signal-regulating kinase-1 (ASK-1), a member of the MAPKKK family. The reduced form of thioredoxin binds to ASK-1 but in the presence of ROS, thioredoxin becomes oxidised and dissociates. This allows the free ASK-1 to promote apoptosis [15].

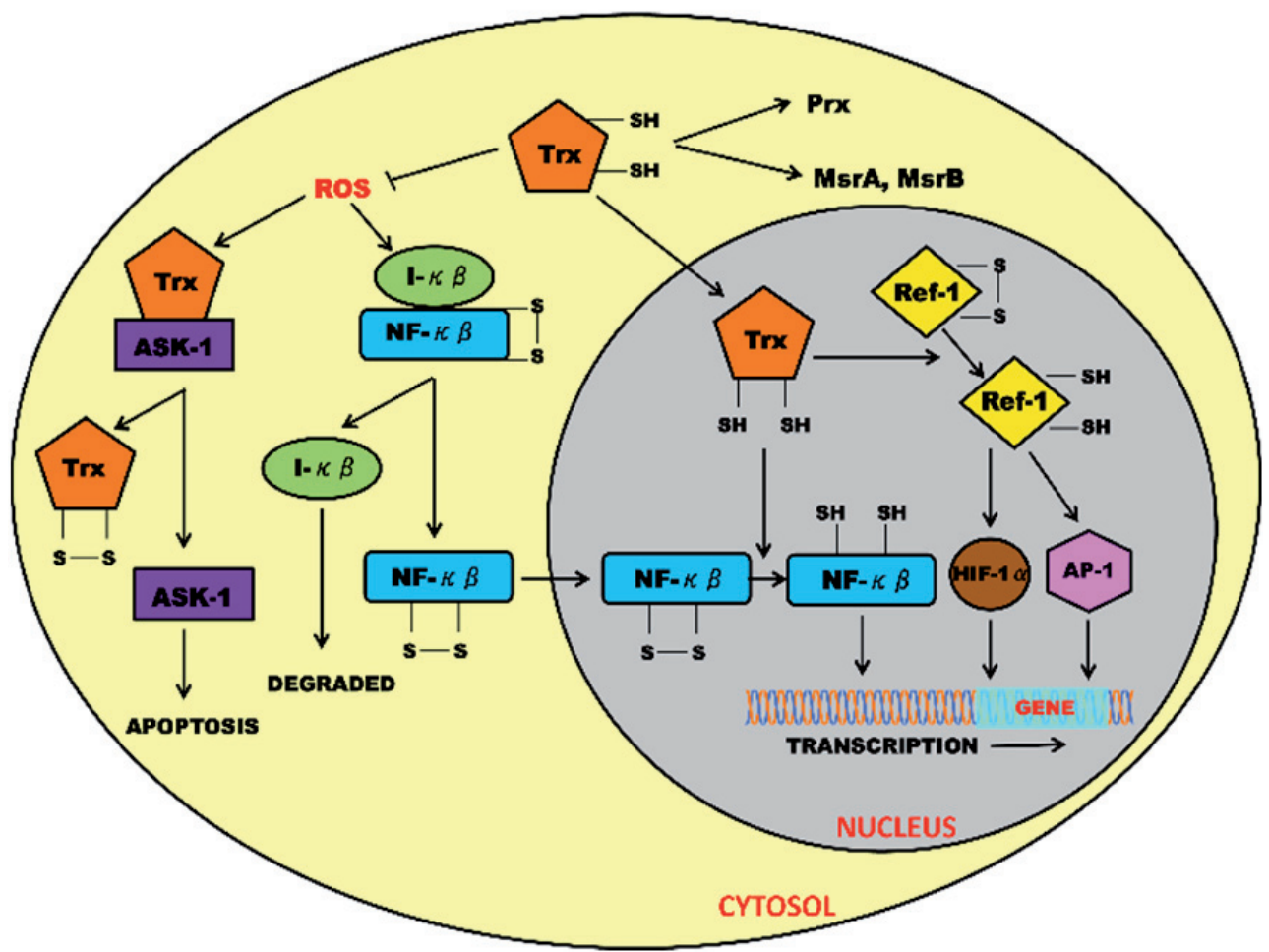

Figure 2. Localisation of thioredoxin with some of its functions and regulatory pathways.

In the nucleus, thioredoxin is responsible for regulating the activity of several transcription factors. Nuclear factor- $\kappa \mathrm{B}(\mathrm{NF}-\kappa \mathrm{B})$ is a transcription factor involved in the regulation of apoptosis and is activated in response to ROS [16]. Under normal conditions, NF- $\mathrm{KB}$ is 


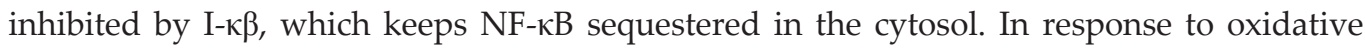
stress, I- $\kappa \beta$ is degraded and releases NF- $\kappa \beta$, which is translocated to the nucleus. In the nucleus, thioredoxin directly reduces Cys62 in the p50 subunit of NF- $\mathrm{B}$, which allows NF$\mathrm{\kappa B}$ to bind to the specific recognition sequence in the promoter of its target genes, such as those involved in cell survival, to induce their expression [16]. Thus, thioredoxin contributes to the upregulation of anti-apoptotic proteins. Thioredoxin can also regulate transcription factors via indirect mechanisms through redox factor-1 (Ref-1), which is an intermediate protein that reduces several other transcription factors to enhance their binding to the promoters of their target genes [17]. Activator protein-1 (AP-1) is a heterodimeric complex of Fos and Jun proteins that binds to the DNA regulatory element known as the AP-1 binding site [18]. AP-1 mediates growth of cells in response to external stimuli. Thioredoxin acts on Ref-1, which in turn activates AP-1 by reducing the highly conserved cysteine residues in the DNA-binding domains of Fos (Cys154) and Jun (Cys272) [17]. Therefore, thioredoxin is also involved in cell growth. Furthermore, under hypoxic conditions, thioredoxin activates HIF-1 through Ref-1.

Thioredoxin is also secreted by a variety of normal and neoplastic cells through an as yet unknown pathway [19]. Secreted thioredoxin has been implicated in immune responses [20, 21] and in cell survival mechanisms [22, 23]. Extracellular thioredoxin has been suggested to have chemotactic activity and to act as chemo-attractant for neutrophils, monocytes and Tcells [24]. Extracellular thioredoxin has also been associated with cancer cell metastasis [25] and the promotion of a matrix metalloproteinase-9 (MMP-9) dependent invasive phenotype in malignant breast cancer cells [26].

\subsection{The thioredoxin system and cancer}

High levels of thioredoxin have been observed in many cancer cells and tumors in response to the elevated levels of oxidative stress these cells are considered to experience. High levels of both thioredoxin and thioredoxin reductase have been observed in the most metastatic tumors [27]. Using prostate cancer cell lines, Chaiswing and colleagues showed that the more invasive cell line displayed a more reduced cellular state [28]. In addition, when two human lung carcinoma cell lines expressing either high or low thioredoxin levels were injected into immuno-deficient mice, the high thioredoxin expressing cell lines resulted in more aggressive tumors being formed [29]. These studies suggest that thioredoxin plays a critical role in promoting tumor progression.

While the specific roles that thioredoxin has in cancer metastasis are yet to be fully identified, it is known to have a role in regulating MMP function. MMPs are involved with extracellular matrix (ECM) degradation, an important aspect of metastasis [30]. MMP activity is regulated by tissue inhibitor of matrix metalloproteinases (TIMPs) [31]. In normal cells, MMP levels are maintained by TIMPs and ECM degradation is inhibited. In tumor cells, the MMP/TIMP balance is disturbed, leading to ECM degradation and subsequent tumor invasion. Addition of extracellular thioredoxin was shown to preferentially inhibit TIMPs, leading to an increase in overall MMP activity and thus, stimulating neuroblastoma 
cell invasion [25]. Recently, it was shown that over-expression of thioredoxin in MDA-MB231 breast cancer cells stimulated MMP-9 expression by upregulating NF- $\mathrm{B}, \mathrm{Sp} 1$ and AP-1 activity and enhancing binding of these transcription factors to the MMP-9 gene promoter. Transfection of a construct expressing a dominant negative redox inactive thioredoxin protein inhibited MMP-9 promoter activity and subsequent NF-кB, SP1 and AP-1 binding [26].

\subsection{Induction of the thioredoxin system by oxidative stress}

The induction of thioredoxin expression during oxidative stress in both normal and cancer cells has been well documented and occurs primarily through an antioxidant response element (ARE) in the thioredoxin gene promoter. ARE elements are short cis-acting elements found in the promoter regions of many genes encoding antioxidant enzymes and they regulate gene expression during oxidative stress [32]. A redox-sensitive transcription factor, nuclear factor (erythroid-derived 2)-like 2 (Nrf2) plays a critical role in mediating the antioxidant gene expression via the ARE element [33]. Nrf2 is ubiquitously expressed in most tissues and is continuously degraded in the cytosol under normal oxygen conditions via its inhibitor "kelch-like erythroid cell-derived protein-1" (Keap1) [34]. Keap1 contains several cysteine residues that act as redox sensors. Upon changes in the cellular oxygen environment, these cysteine residues are oxidised [35]. As a result, Keap1 undergoes a conformational change and releases Nrf2, which is translocated into the nucleus [32]. In the nucleus, Nrf2 forms a heterodimer with small maf proteins and binds to the ARE of the target antioxidant genes [36], including thioredoxin [37] and thioredoxin reductase [38] (Figure 3).

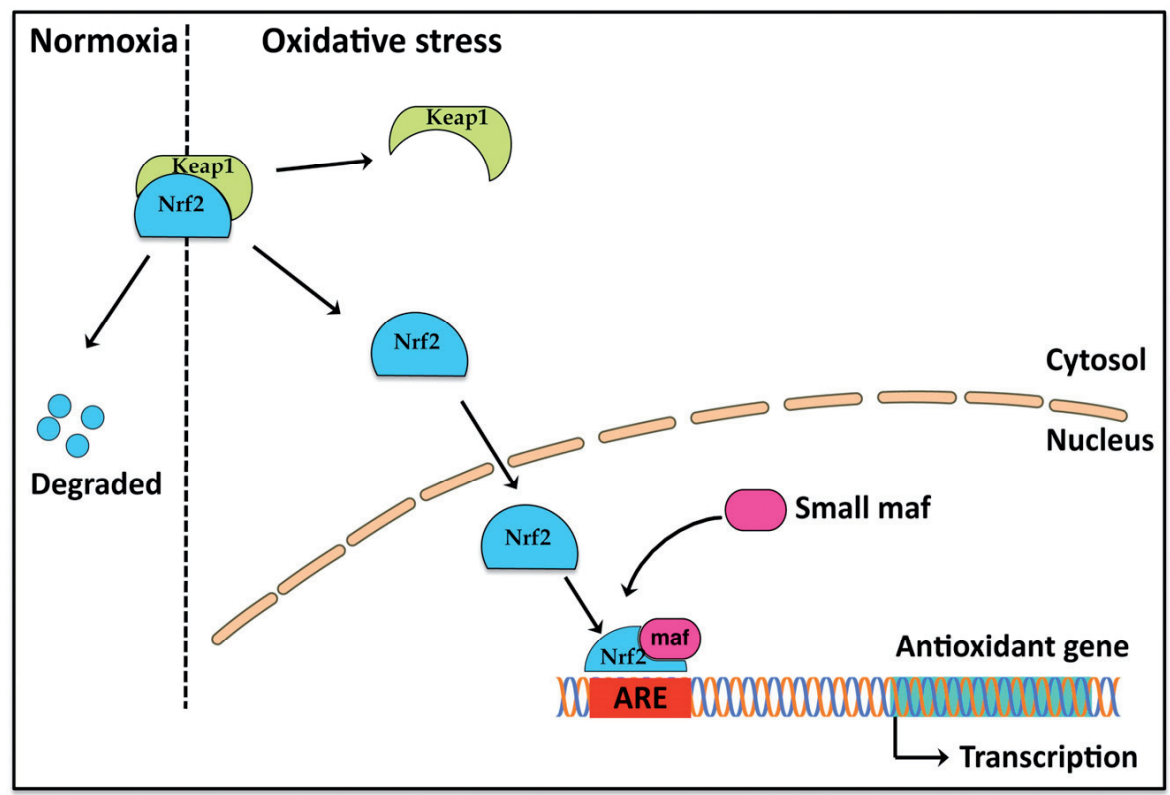

Figure 3. Antioxidant gene expression via the ARE/Nrf2 pathway. 


\section{The HIF-1 signaling pathway}

Hypoxia-inducible factor-1 (HIF-1) is an important transcription factor that regulates the expression of several vital genes in response to oxygen deficient conditions [3]. These include genes encoding metabolic enzymes to allow growth under hypoxia and proteins that assist hypoxic tissues to re-establish oxygen supply. Of particular relevance to tumors, HIF-1 induces the expression of vascular endothelial growth factor (VEGF), which is required for angiogenesis. HIF-1 transcription factor is a complex of two subunits: aryl hydrocarbon receptor nuclear translocator (ARNT), also known as HIF-1 $\beta$, which is constitutively expressed in all cells, and HIF- $\alpha$, which is stabilised under hypoxia. Normally, HIF- $\alpha$ is synthesized and continuously degraded in the cytosol, but in response to a low oxygen environment it starts accumulating rapidly [39]. HIF- $\alpha$ is then translocated into the nucleus, where it dimerises with HIF-1 $\beta$ to form the HIF-1 complex, which then binds to the hypoxia responsive element (HRE) in the promoters of target genes to activate their expression [3] (Figure 4).

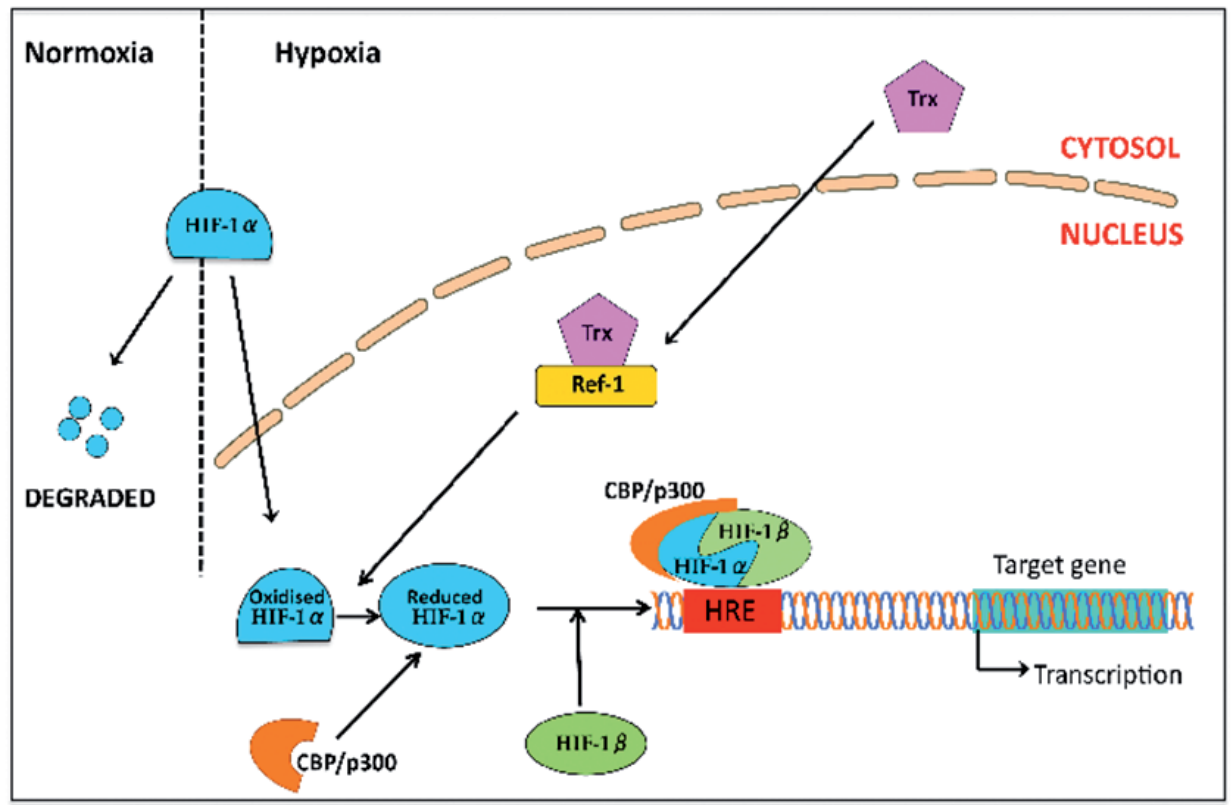

Figure 4. Regulation of the HIF-1 signaling pathway and the expression of its target genes.

\subsection{HIF-1 proteins and hypoxic regulation}

Both HIF-1 subunits belong to the basic helix-loop-helix (bHLH)/Per-ARNT-Sim (PAS) family of transcription factors. The bHLH domain aids in DNA-binding while the PAS domain mediates protein-protein interaction. Both domains also act as an interface for dimerisation of the $\alpha$ and $\beta$ subunits [40]. There are three identified HIF- $\alpha$ subunits [3] and one $\beta$ subunit, which is alternatively spliced [41]. HIF- $1 \alpha$ is the most characterised form and will be discussed in this chapter. HIF- $1 \alpha$ and HIF- $2 \alpha$ have structurally similar DNA binding 
and dimerisation domains, but they differ in their transactivation domains. This may explain why a genome wide screen detected both HIF-1 $\alpha$ and HIF-2 $\alpha$ bound to the same HRE consensus sites, but without initiating the same transcriptional response [42]. Moreover, HIF-2 $\alpha$ is only expressed in certain tissues [43], while HIF- $1 \alpha$ is ubiquitously expressed. Overall their biological actions in response to hypoxia are distinct, as reviewed by Loboda and colleagues [44]. For example, HIF-1 $\alpha$, but not HIF-2 $\alpha$ regulates the transcription of genes encoding enzymes involved in glycolysis [45], while HIF-2 $\alpha$ has been associated with adaptation to high altitude exposure [46]. Furthermore, Bracken and coworkers showed in PC12 rat cells that HIF-1 $\alpha$ required a shorter duration (4h) under hypoxia to be stabilized, whereas a longer hypoxic exposure (16h) was required for HIF-2 $\alpha$ stabilization. However, this difference was cell-line specific [47]. In human colon cancer, advanced tumors displayed strong HIF- $1 \alpha$ staining and weak HIF- $2 \alpha$ staining, while in early stage tumors, strong HIF- $2 \alpha$ and weak HIF- $1 \alpha$ staining was observed. This implies that HIF$1 \alpha$ and HIF- $2 \alpha$ have different roles in colon cancer [48]. In contrast, HIF-3 $\alpha$ has inhibitory function since it lacks the transactivation domain, but binds to HIF-1 $\alpha$ and prevents it from activating transcription. Therefore, HIF- $3 \alpha$ is also called 'inhibitory PAS domain' (IPAS) and arises as an alternatively spliced product of the HIF-1 $\alpha$ gene [49].

There are two transactivation domains in HIF-1 $\alpha$ : the amino-terminal transactivation domain (NAD) and the carboxy-terminal transactivation domain (CAD) [50, 51]. These domains are involved in the transcriptional activation of HIF-1 $\alpha$ under hypoxia. The NAD overlaps the oxygen-dependent degradation domain (ODD), linking the transcriptional activity of HIF-1 with the stabilisation of the protein [50]. On the other hand, the transcriptional activity of the $\mathrm{CAD}$ is associated with the binding of transcriptional coactivators, including CREB-binding protein (CBP)/p300 [52]. The recruitment of the coactivators is redox-regulated and requires Ref- 1 , which reduces the cysteine residue at position 800 of HIF-1 $\alpha$ within the CAD region [53]. The co-activators are then able to bind HIF-1 and subsequently initiate transcription. It should be noted that Ref- 1 is an intermediate protein that is regulated by thioredoxin.

\subsection{Regulation of HIF-1 under normoxia}

Although the HIF-1 $\alpha$ proteins are activated in response to hypoxia, they do not sense the changes in the oxygen environment themselves. Sensors to such changes have been identified as oxygen-dependent hydroxylases. The hydroxylases responsible for modifying HIF-1 $\alpha$ are the 'prolyl hydroxylase domain-containing proteins' (PHDs) and an asparaginyl hydroxylase called 'Factor Inhibiting HIF-1' (FIH-1) [54]. These hydroxylases continuously modify HIF-1 $\alpha$ in presence of oxygen. When there is a negative change in oxygen availability, PHDs and FIH-1 can no longer hydroxylate HIF-1 $\alpha$, which is stabilised and translocated to the nucleus [55] (Figure 5).

Under higher oxygen conditions, PHDs modify distinct proline residues (Pro 402 and Pro 564 ) in the ODD domain of HIF-1 $\alpha$ [56], leading to the recruitment of von Hippel-Lindau (VHL) proteins [57] and subsequent degradation of HIF-1 $\alpha$ [58]. The PHD family has three 
members: PHD1, PHD2 and PHD3, with PHD2 being the most abundant and highly active towards HIF-1 $\alpha$ [59]. PHDs require only a short stretch of HIF-1 $\alpha$ amino acids (as short as 20 residues) for the selective recognition of proline hydroxylation sites and subsequent VHLbinding. These sites reside within an LXXLAP motif, which is highly conserved between the HIF- $\alpha$ isoforms as well as across species [58]. The hydroxylation enables the VHL protein to bind HIF-1 $\alpha$, which initiates degradation via the ubiquitination pathway [58, 60]. VHLdeficient cells have the HIF-1 $\alpha$ subunit constitutively stabilised and thus, HIF-1 is constantly activated in these cells [57].

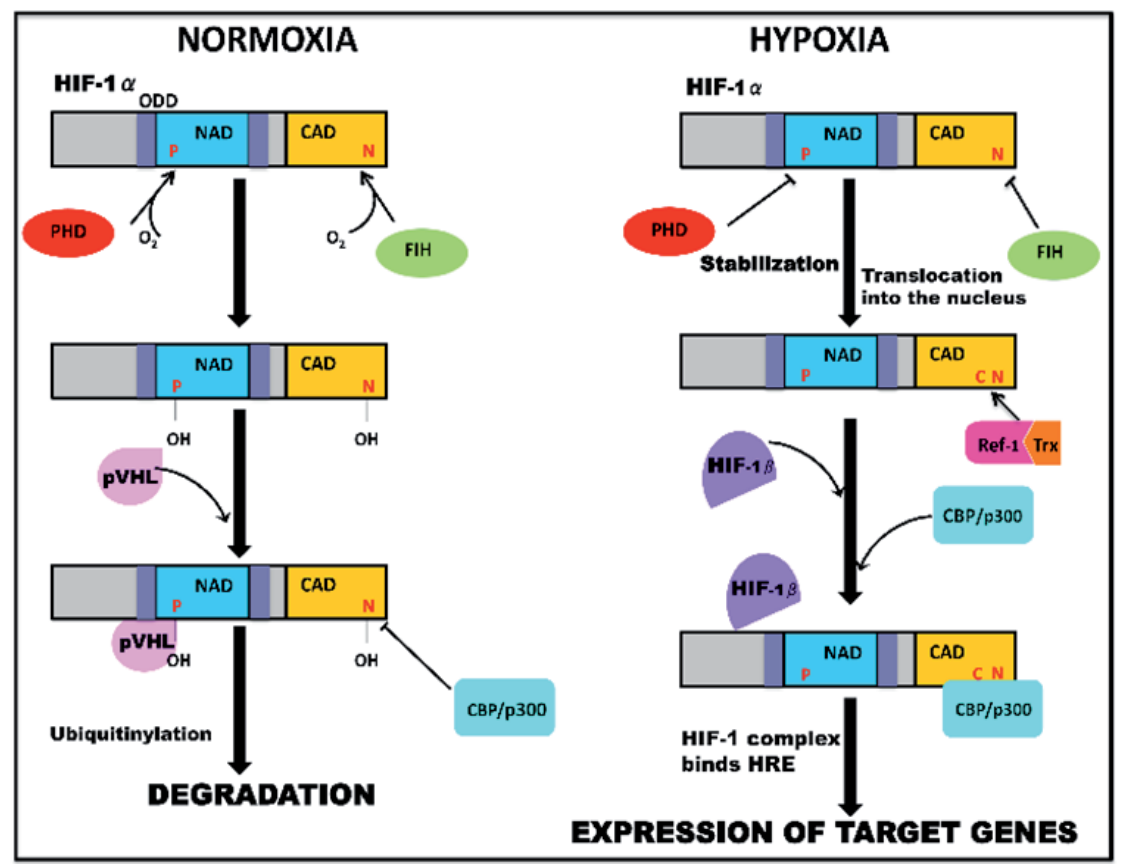

Figure 5. Regulation of HIF-1 $\alpha$ during normoxia and hypoxia.

An additional hydroxylation event in the CAD domain ensures that any HIF-1 $\alpha$ that escapes degradation is rendered inactive. This process involves the hydroxylation of an asparagine residue instead of a proline and suppresses the recruitment of CBP/p300 co-activators [54]. This asparaginyl hydroxylase is the FIH-1, and uses both HIF-1 $\alpha$ and HIF-2 $\alpha$ as substrates. In HIF-1 $\alpha$, FIH-1 hydroxylates an asparagine residue at position 803 . FIH-1 is an Fe(II)dependent enzyme and plays the role of a second oxygen sensor within the hypoxic response pathway [61].

Thus, under normoxia, prolyl and asparaginyl hydroxylases prevent the activation of HIF$1 \alpha$ by acting on the NAD and CAD domains respectively. However, when oxygen levels decrease, these hydroxylases become inactive, HIF-1 $\alpha$ proteins are stabilised and translocated to the nucleus where they dimerise with HIF-1 $\beta$. The reduction of a key cysteine residue in the CAD by Ref- 1 , through the action of thioredoxin, results in the recruitment of transcriptional co-activators and subsequent expression of the target genes. 


\subsection{Regulation of the HIF-1 system by ROS}

While HIF-1 is stabilised and active under conditions of low oxygen, paradoxically ROS can also stabilise HIF-1. Under normoxia, the addition of $\mathrm{H}_{2} \mathrm{O}_{2}$ caused HIF- $1 \alpha$ stabilisation and enhanced expression from HRE-reporter constructs [62]. In addition, Hep3B $\rho^{0}$ cells, which do not have mitochondrial electron transport function, can exhibit HRE-luciferase reporter activity under normoxia upon addition of $\mathrm{H}_{2} \mathrm{O}_{2}$ [62]. The molecular basis for ROS stabilising HIF-1 was shown by exposing murine breast tumor cells to nitric oxide (NO). Addition of NO caused nitrosylation of a specific cysteine residue in the ODD domain of HIF-1 $\alpha$ under normoxia. The VHL protein was therefore unable to bind to HIF-1 $\alpha$, thereby preventing its degradation [63]. This represents a control mechanism that bypasses the function of the PHD enzymes under normoxia, since the nitrosylation did not prevent or change the level of proline hydroxylation detected in the NAD domain.

ROS is also believed to play a role in the HIF-1 signaling pathway during hypoxia. Cells with non-functional mitochondria, and therefore, reduced ROS levels, were unable to stabilise HIF- $1 \alpha$ in response to hypoxia $[62,64]$. When $\mathrm{H}_{2} \mathrm{O}_{2}$ was inhibited by catalase overexpression in human 293 cells under hypoxia, there was reduced HRE-luciferase reporter activity, suggesting lower HIF-1 $\alpha$ activity, which was restored by the addition of $\mathrm{H}_{2} \mathrm{O}_{2}$ [62] . These observations suggest that the presence of $\mathrm{H}_{2} \mathrm{O}_{2}$ in the cytosol is necessary for HIF-1 $\alpha$ stabilisation under hypoxia. One possible role of ROS may be to inhibit the PHD enzymes. Addition of $10 \mu \mathrm{M} \mathrm{H}_{2} \mathrm{O}_{2}$ showed more than $50 \%$ inhibition of PHD enzyme function in vitro but did not increase HIF-1 $\alpha$ transcriptional activity in Hep3B cells [65]. This is implies that HIF-1 $\alpha$ activation by ROS can occur through multiple pathways including both stabilisation and recruitment of co-activators.

While ROS appears to exert some regulatory function on HIF-1, there is still debate as to whether ROS levels are increased [62, 66, 67] or decreased [68-70] during hypoxia. Contradictory results may occur due to differences in cell type, mode of generating hypoxia, oxygen levels and assays used to measure ROS. Work from our laboratory demonstrated that MDA-MB-231 breast cancer cells grown under hypoxia have reduced ROS levels [68]. However, we found that how the cells were processed was extremely important. If cells were processed under normoxic conditions following the hypoxic growth then increased ROS levels were observed. When cells were maintained under hypoxia throughout the processing steps, then a decrease was evident [68]. This indicates that cells grown in hypoxia must be maintained in hypoxia during processing to avoid introduction of an inadvertent reoxygenation step (however brief), thus, mimicking the intermittent hypoxia observed in tumors.

\subsection{Redox regulation of the HIF-1 system}

The activity of the HIF-1 system is regulated by the thioredoxin redox system, via Ref-1. Thioredoxin provides the reducing potential for Ref- 1 to reduce a cysteine residue in the CAD domain of HIF-1 $\alpha$ that enhances the ability of HIF-1 to recruit co-activators [53]. 
Consequently, cell lines engineered to over-express thioredoxin also displayed increased HIF-1 $\alpha$ levels, enhanced HIF-1 DNA binding and increased activation of HIF-1 regulated gene promoters. This results in increased levels of hypoxia regulated proteins such as VEGF [71, 72] and cyclooxygenase-2 (COX-2) [73]. In contrast, when cells were transfected with the dominant negative redox inactive thioredoxin protein, VEGF and COX-2 levels were decreased. Other small molecule inhibitors of the thioredoxin system, such as quinols, also led to down regulation of HIF-1 activity [72] and subsequently to a decrease in VEGF and inducible nitric oxide synthase (iNOS) expression in MCF-7 breast cancer cells [74].

A recent study showed that thioredoxin reductase levels were decreased during hypoxia and as a consequence higher ROS levels were observed [75]. They concluded that hypoxia does not increase mitochondrial ROS production, but that lower thioredoxin reductase levels are responsible for higher ROS levels. Since HIF-1 is also regulated by ROS, this study demonstrated that the thioredoxin redox system could modulate HIF-1 signalling by indirectly affecting ROS levels, in addition to the direct interaction described above.

\section{Redox and hypoxic systems: the intermittent hypoxia link}

The tumor environment is in flux between hypoxia and reoxygenation. Hypoxia induces the formation of new blood vessels, which are often poorly formed, causing an inconsistent oxygen supply [7]. Therefore, cells can experience a cycling between hypoxia and reoxygenation. Hypoxic pathways are induced during periods of low oxygen while the reoxygenation results in induction of antioxidant proteins, including the redox enzymes. Thus, the interplay between the two systems is important to study in tumors. Interestingly, the cycling between hypoxia and reoxygenation enhances HIF-1 activity. Many of the studies undertaken to assess the role of HIF-1 and redox signaling in cancer are performed using cancer cell lines. Therefore, each cancer cell line should be evaluated for its suitability as a model system for intermittent hypoxia.

\subsection{Use of an in vitro model system for intermittent hypoxia}

The MDA-MB-231 breast cancer cell line is often used as an in vitro model system for metastatic cancer. However, most researchers grow these cells under what is usually regarded as normoxia, that is $20 \%$ oxygen, despite this not being physiologically relevant. We wanted to assess the suitability of this cell line for hypoxic cycling studies. Our first aim was to determine the most appropriate level of oxygen to use to ensure a strong hypoxic response is generated. We assayed the lactate dehydrogenase (LDH) activity present in MDA-MB-231 cells grown in either $1 \%$ oxygen or $0.1 \%$ oxygen. $\mathrm{LDH}$ is a glycolytic enzyme, which is upregulated in response to hypoxia through the binding of HIF-1 to an HRE element in its gene's promoter [76]. Cells were cultured in $5 \% \mathrm{CO}_{2}$ with either $1 \%$ oxygen or $0.1 \%$ oxygen for 24 hours in a hypoxic C-chamber (Biospherix, New York, USA), and then lysed within a C-shuttle glovebox (Biospherix) using a buffer comprised of $150 \mathrm{mM} \mathrm{NaCl}, 50$ $\mathrm{mM}$ Tris- $\mathrm{HCl} \mathrm{pH}$ 8.0, $0.5 \%$ (v/v) Nonidet P-40, $0.5 \mathrm{mM}$ EDTA, $2 \mathrm{mM} \mathrm{PMSF}, 1 \mu \mathrm{l} / \mathrm{ml}$ proteinase inhibitor cocktail VI (AG-Scientific, California, USA). Protein estimation was 
performed using the DC protein assay kit (BioRad, NSW, Australia) and equal amounts of cell lysate were used to measure LDH activity. The assay buffer contained $50 \mathrm{mM}$ Tris- $\mathrm{HCl}$ $\mathrm{pH} 7.5,1 \mathrm{mg} / \mathrm{ml} \mathrm{NADH}, 1 \mathrm{mg} / \mathrm{ml}$ pyruvate and the LDH activity was measured at $340 \mathrm{~nm}$ using a Spectromax Plate reader. The results are presented in Figure 6. The data is expressed as a change in percentage of LDH activity relative to normoxic treated cells, with normoxia represented as $100 \%$. While cells grown at both $1 \%$ and $0.1 \%$ oxygen levels showed an increase in LDH activity, only cells grown in $0.1 \%$ oxygen had a statistical significance compared to cells grown under normoxia.

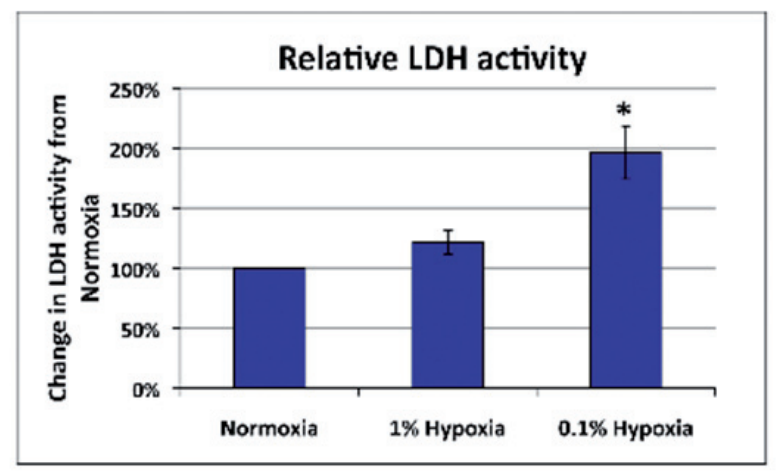

Figure 6. Relative LDH activities in MDA-MB-231 cells after 24 hours of $1 \% \mathrm{O}_{2}$ or $0.1 \% \mathrm{O}_{2}$ growth. Normoxia and $0.1 \%$ hypoxia treated cells showed significant difference using a one-way ANOVA employing Tukey's Post-Hoc test, as indicated by * $(\mathrm{p}<0.05)$. Data presented as mean \pm SEM from three independent experiments conducted in triplicate.

We then wanted to assess the morphology and viability of the MDA-MB-231 cells grown under various oxygen growth conditions. We selected $0.1 \%$ oxygen as the hypoxic condition to culture these cells in, to ensure a strong hypoxic response. The MDA-MB-231 cells were grown under prolonged hypoxia (16 hours) followed by different lengths of reoxygenation by transferring cells to $20 \%$ oxygen (referred to as normoxia). To assess the effect of cycling hypoxia, cells were also subjected to 4 pre-conditioning (PC) cycles (comprising 10 minutes hypoxia and 20 minutes reoxygenation) prior to the hypoxic growth phase. These different conditions are illustrated in Figure 7. The cycling between hypoxia and normoxia was repeated four times within a 2 hour period before cells were transferred into prolonged hypoxia for 16 hours. Since $20 \%$ oxygen is much higher than $0.1 \%$ oxygen switching to normoxia results in a reoxygenation step. After cells were grown in $0.1 \%$ hypoxia for 16 hours they were either processed using the hypoxic C-Shuttle glovebox to maintain hypoxic conditions or re-oxygenated by being transferred to normoxic conditions for 2, 4 or 6 hours. These cells were processed under normoxia.

To confirm that cells were viable under these oxygen growth conditions, a fluorescence activated cell sorting (FACS) based assay was used. Cells were harvested and detached using cell dissociation buffer (Life Technologies), washed in phosphate buffered saline (PBS) $\mathrm{pH} 7.4$, and then resuspended at a concentration of $1 \times 10^{6}$ cells $/ \mathrm{ml}$ containing an appropriate dilution of 7 -aminoactinomycin $\mathrm{D}$. The cells were then stored on ice until they were 


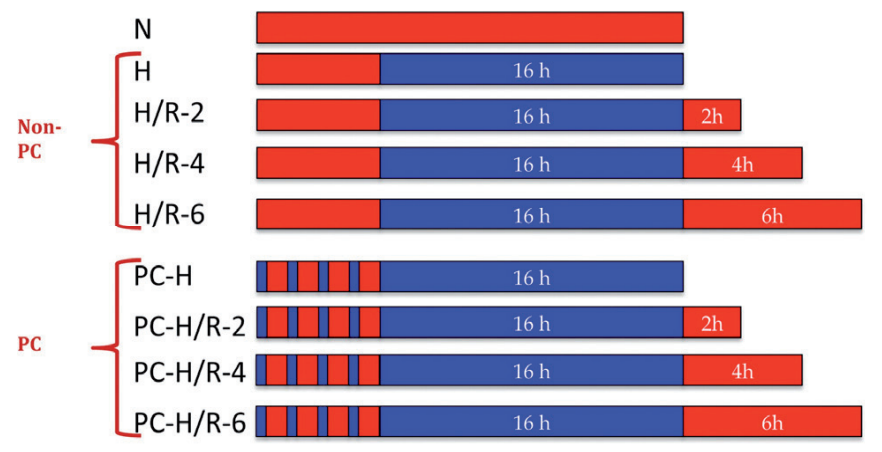

Figure 7. Oxygen growth conditions used to grow MDA-MB-231 cells. Schematic representation outlining the different combinations of hypoxia and reoxygenation and their respective length of exposure used to grow MDA-MB-231 cells. Red indicates growth under $20 \%$ oxygen. Blue indicates growth in $0.1 \%$ oxygen. N: normoxia ( $20 \%$ oxygen); R: reoxygenation; H: hypoxia; PC: pre-conditioning.

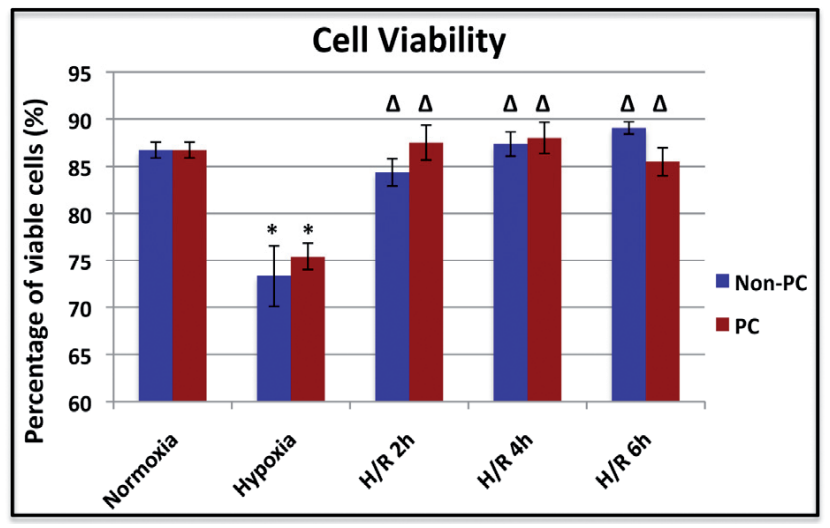

Figure 8. Viability of MDA-MB-231 cells in response to different oxygen growth conditions. Non-PC treated samples and PC treated samples were analysed separately using a one-way ANOVA employing Tukey's Post-Hoc test. A statistical difference was observed compared to normoxia, as indicated by * $(\mathrm{P}$ $<0.01)$. A statistical difference was observed for all reoxygenation samples compared to hypoxic cells, as indicated by $\Delta(\mathrm{p}<0.01)$. Data is presented as mean \pm SEM from at least two independent experiments.

analysed for viability using the BD FACSAria flow cytometer (BD Biosciences). The results are shown in Figure 8. Upon growth in hypoxia cellular viability decreases, while after reoxygenation cell viability returns to levels consistent with those of cells grown in normoxia. A decrease in cell viability following hypoxic growth has also been observed by other researchers using different cell lines [77, 78].

The morphology of the cells grown in each oxygen growth condition was assessed by microscopy. Cells were also grown in media containing $100 \mu \mathrm{M} \mathrm{H}_{2} \mathrm{O}_{2}$ for 30 minutes as a control for oxidative stressed cells. After exposing MDA-MB-231 cells to different oxygen growth conditions, cell morphology was examined under an Olympus CK30 microscope (Olympus Co., Japan) at 100X magnification. Experiments were performed multiple times with representative images shown in Figure 9. Cells exposed to $100 \mu \mathrm{M} \mathrm{H}_{2} \mathrm{O}_{2}$ for 30 minutes 

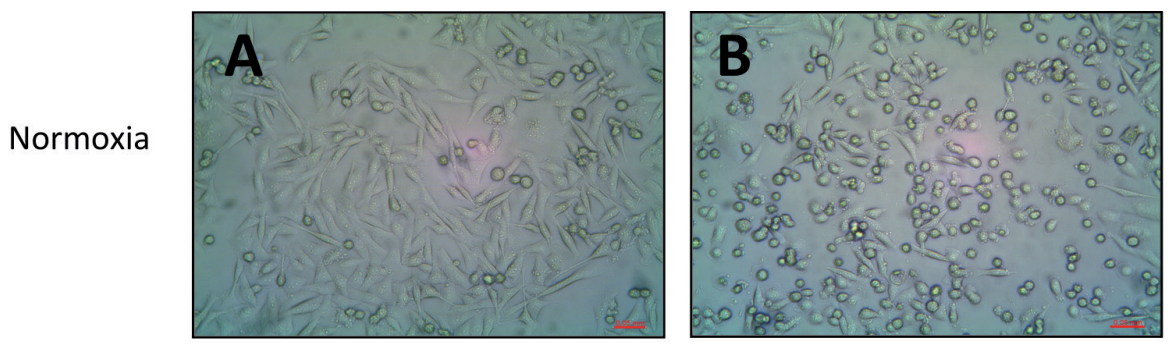

$\mathrm{H}_{2} \mathrm{O}_{2}$
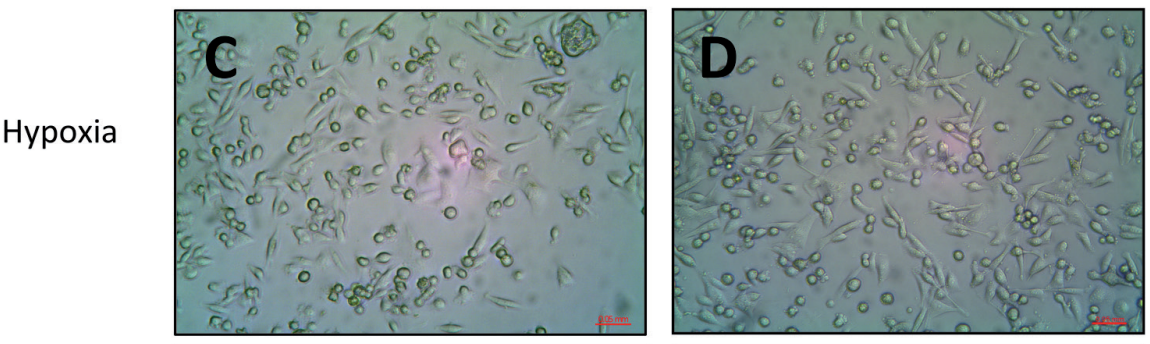

PC-H

$\mathrm{H} / \mathrm{R} 2 \mathrm{~h}$
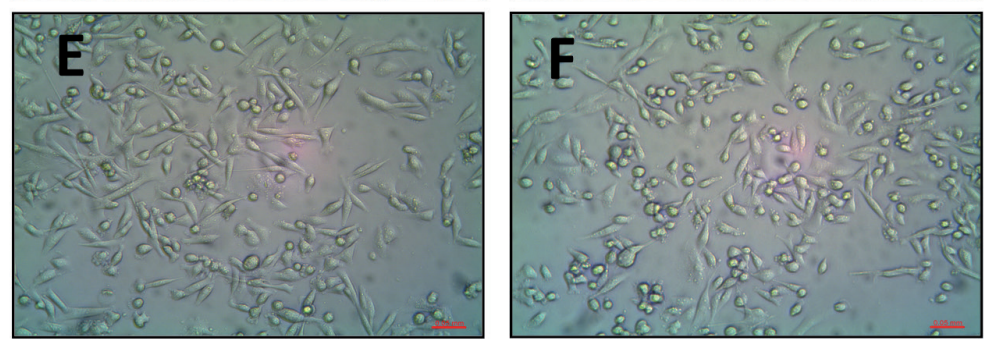

$\mathrm{PC}-\mathrm{H} / \mathrm{R} 2 \mathrm{~h}$
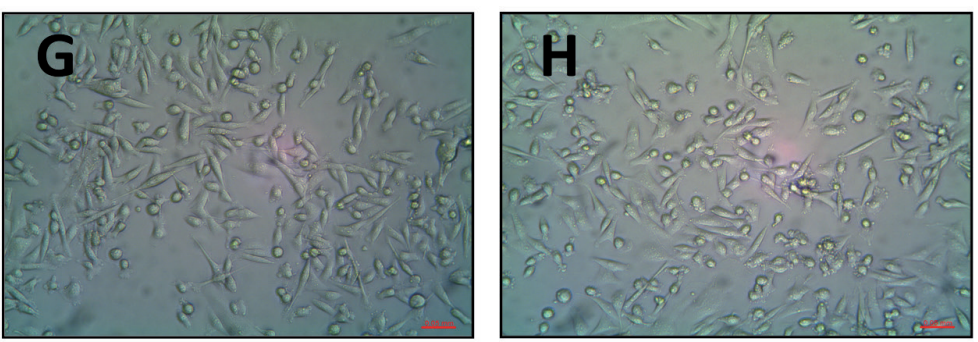

$\mathrm{PC}-\mathrm{H} / \mathrm{R}$ 4h

$\mathrm{H} / \mathrm{R} 4 \mathrm{~h}$
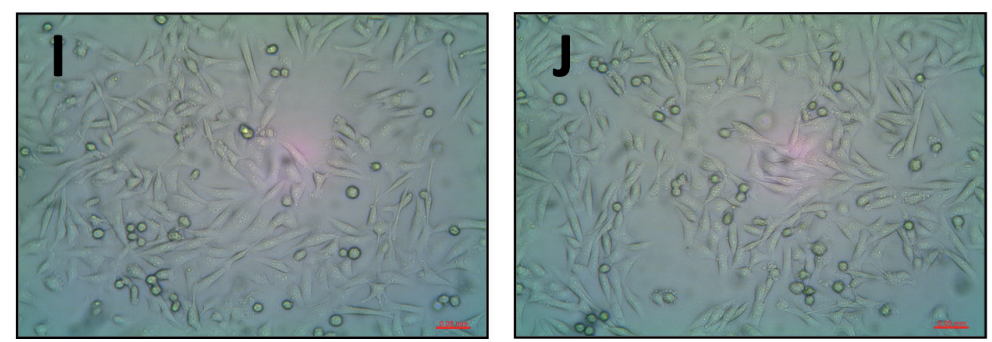

PC-H/R 6h

Figure 9. Morphology of MDA-MB-231 cells after different oxygen growth treatments. A): Normoxia treated cells, B): $100 \mu \mathrm{M} \mathrm{H}_{2} \mathrm{O}_{2}$ treated cells, C): 0.1\% hypoxia treated cells, D): PC-H treated cells, E): H/R 2h treated cells, F): PC-H/R 2h treated cells, G): H/R 4h treated cells, H): PC-H/R 4h treated cells, I): H/R 6 h treated cells, J): PC-H/R 6h treated cells. Images were taken using an Olympus CK30 microscope at 100X magnification. Scale bar $=0.05 \mathrm{~mm}$. 
(Figure 9B) exhibited altered cell morphology compared to normoxia treated cells (Figure 9A). These cells appeared to be less elongated and more rounded in shape. The cells exposed to hypoxia (Figure 9C) or PC-hypoxia (Figure 9D) showed a similar morphology to $\mathrm{H}_{2} \mathrm{O}_{2}$ treated cells. When hypoxia or PC-hypoxia treated cells were exposed to a longer period of reoxygenation (Figure 9I and J) their morphology becomes very similar to that of the normoxia treated cells. This trend suggests that the cells become stressed when exposed to hypoxia but recover during the reoxygenation phase. No difference was observed in overall morphology between hypoxia (Figure 9C) or PC-hypoxia (Figure 9D) treated cells or their respective reoxygenation exposures (Figure 9E, G and I compared to Figure 9F, H and $\mathrm{J}$, respectively).

Since various methodologies are used to generate hypoxia it is important to establish the appropriate conditions for each cell line. MDA-MB-231 cells grown at $0.1 \%$ oxygen elicited a hypoxic response, whereas $1 \%$ oxygen did not induce a significant hypoxic response. A decrease in cellular viability in response to hypoxia was observed compared to normoxia, but returned to normal levels during reoxygenation. Cells also exhibited a more rounded morphology during hypoxia, consistent with a stress response. The recovery of the cells during reoxygenation suggests that signaling pathways are involved that enable cells to adapt to these changing oxygen conditions, with the most likely candidates being the HIF-1 and redox-dependent pathways.

\subsection{Expression of the HIF-1 system under intermittent hypoxia}

Several studies have implicated an upregulation in levels of the HIF-1 transcription factor under intermittent hypoxia. This increase supersedes the HIF-1 levels found in acute hypoxia [79, 80]. Yuan and co-workers found this to be $\mathrm{Ca}^{+2}$ dependent [80]. They demonstrated the involvement of calcium-calmodium dependent kinase II (CaMK II) under intermittent hypoxia. CaMK II phosphorylates p300, a co-activator required for the transcriptional activity of HIF-1, thereby increasing the HIF-1 transactivation [80]. In contrast, under acute hypoxia, HIF-1 transcriptional activity is increased as a result of a decrease in the $\mathrm{O}_{2}$ dependent asparaginyl hydroxylation in the CAD region of HIF-1 $\alpha$, assisting in the recruitment of co-activators [54].

Intermittent hypoxia has been linked to increased tumor invasion and resistance against radiotherapy [81, 82] and to enhanced metastasis in rodent lungs [83]. Liu and colleagues demonstrated that intermittent hypoxia treated H446 lung cancer cells had a greater metastatic ability and radio-resistance. They found HIF-1 $\alpha$ was involved in both processes [84]. Intermittent hypoxia exposed endothelial cells also showed enhanced migration and exhibited an increased resistance against irradiation as compared to their counterparts grown in normoxia or acute hypoxia. This effect was also mediated by HIF-1 $\alpha$ since siRNA targeting HIF- $1 \alpha$ abolished the radiation resistance [82]. Therefore, HIF- $1 \alpha$ may be expected to have a role in tumor invasion observed under intermittent hypoxia.

Differences in expression of HIF-1 $\alpha$ and HIF-2 $\alpha$ under acute and intermittent hypoxia have been shown in sleep-disordered breathing. While intermittent hypoxia caused an 
upregulation in HIF-1 $\alpha$ levels, the HIF- $2 \alpha$ levels were down-regulated in intermittent hypoxia treated rat PC12 cells and also in in vivo rat models. In contrast, acute hypoxia upregulated both HIF-1 $\alpha$ and HIF-2 $\alpha$ [85]. It was proposed that down-regulation of HIF-2 $\alpha$ contributes to oxidative stress, at least in part via transcriptional down-regulation of a HIF-2 target gene, an antioxidant called superoxide dismutase (SOD). Intermittent hypoxia also increased ROS by decreasing the mitochondrial complex I activity. The increase in ROS levels was linked to the upregulated HIF-1 $\alpha$ levels under intermittent hypoxia [86]. Therefore, the differential regulation of HIF- $1 \alpha$ and HIF- $2 \alpha$ is believed to cause oxidative stress resulting from an imbalance between ROS and antioxidants [85]. Similar mechanisms may contribute to higher levels of ROS in cancer cells. However, as antioxidants are proteins that scavenge ROS, one may expect that antioxidant levels would be augmented in such a scenario. Interestingly, a number of studies implicate an upregulation of antioxidants in cancer cells cultured under intermittent hypoxia.

\subsection{Expression of redox enzymes under hypoxia and intermittent hypoxia}

Since intermittent hypoxia involves phases of reoxygenation, it is reasonable to expect that redox enzymes would be induced during these reoxygenation phases. The expression of thioredoxin during the hypoxic phase has been less clear. In hypoxic regions of tumors, thioredoxin expression has been reported as high [87], but intermittent hypoxia may contribute to this high expression. In cells cultured in vitro there has been conflicting reports regarding thioredoxin expression levels under hypoxia.

Thioredoxin protein levels were increased in A549 human lung cancer cells during growth in $0.05 \%$ oxygen [88] and in both human endothelial progenitor cells and human umbilical vein endothelial cells cultured in $1 \%$ oxygen [78], as assessed by Western blotting. Our work [68] showed a visible increase (by Western blotting) in thioredoxin levels in MDA-MB-231 cells cultured in $0.1 \%$ hypoxia, but this increase was not statistically significant. In addition, neither thioredoxin nor thioredoxin reductase promoter activity was increased under hypoxia [68]. Ref-1 protein levels were also not increased [68] while other studies reported that peroxiredoxin protein levels were not increased in A549 cells cultured in hypoxia [89]. A recent study showed a decrease in thioredoxin reductase protein levels under hypoxia [75]. Previously, it was reported that thioredoxin reductase was increased in human endothelial progenitor cells but not in human umbilical vein endothelial cells under hypoxia [78]. This conflicting data suggests that as with the variable ROS levels reported under hypoxia, expression of the thioredoxin system under hypoxia may depend on the specific cell line, oxygen levels or how samples are processed. For example, Jewell and co-workers observed that thioredoxin levels in the nucleus were increased after as little as 30 seconds of oxygen exposure following hypoxic growth [90]. Thus, in some reported cases, cells may have received an inadvertent reoxygenation stimulus during processing of cells after hypoxic growth, which was sufficient to induce antioxidant gene expression.

Since reoxygenation stimulates the production of ROS, one might expect that high levels of thioredoxin would be detected in cells reoxygenated after hypoxia. However, this appears 
not to be the case. In our studies [68] MDA-MB-231 cells cultured in 0.1\% oxygen followed by reoxygenation had increased thioredoxin levels as assessed visually on Western blots, but this was statistically non-significant when quantitated by densitometry. In addition, after 6 hours of reoxygenation, the levels were visually decreasing. This correlates with other studies that reported a visible decrease in thioredoxin protein levels in A549 cells grown in $0.2 \%$ oxygen followed by 6 hours or more of reoxygenation [91]. Their work showed that thioredoxin was oxidised during the reoxygenation phase [91], probably by the increased ROS levels [68]. After 6 hours of reoxygenation, ROS levels start to decrease and it is possible that the cells no longer require thioredoxin. No change in Ref- 1 was observed during reoxygenation [68], but peroxiredoxin 1 expression was increased [89].

When conditions mimicking intermittent hypoxia are utilized, the involvement of thioredoxin is quite apparent. Malec and co-workers utilized several different schemes to grow A549 cells alternating between hypoxia and reoxygenation [92]. While a maximum of three 2-hour cycles were used for either hypoxia or reoxygenation, the schemes with the greatest number of cycles of hypoxia and reoxygenation resulted in the highest thioredoxin levels. Nrf2 was also increased under these conditions and may be responsible for the increased thioredoxin expression [92]. Our work [68] used a scheme that mimicked an ischemia/reperfusion study performed in the heart [93]. In that study, 4 short cycles of ischemia and reperfusion (of 10 and 20 minutes respectively) prior to longer-term growth in ischemia and subsequent reperfusion led to very high levels of thioredoxin. These preconditioning conditions also provided the heart protection from damage otherwise caused by the longer-term ischemia and reperfusion. We applied these oxygen growth conditions (Figure 7) to cancer cells and also detected high levels of thioredoxin in cells pre-conditioned with short cycles of hypoxia and reoxygenation followed by a longer exposure to hypoxia and reoxygenation [68]. Maximum thioredoxin protein levels were obtained after 4 hours of reoxygenation, which was confirmed to be statistically significant. These short cycles may also represent what happens in tumors due to red blood cell flux [7] and may provide the tumor with protection against subsequent oxidative insult. Without the pre-conditioning cycling, thioredoxin levels were not increased by as much during reoxygenation, indicating that the cycling may provide an advantage to the cells. Of interest is that Ref- 1 levels were also higher in MDA-MB-231 cells subjected to the pre-conditioning, but not in cells grown without this step [68]. Since Ref-1 and thioredoxin regulate HIF-1 activity, the short pulses of hypoxia may be responsible for their induction. We found that the promoter activity of both thioredoxin and thioredoxin reductase were dependent on Nrf2 in the reoxygenation phase, and that cells cultured with the pre-conditioning cycles did not exhibit higher promoter activity [68]. Therefore, the mechanism for inducing higher thioredoxin protein levels in cells subjected to cycling may not be at the transcriptional level.

\subsection{The Interaction of redox and hypoxic pathways under intermittent hypoxia}

Cancer cells can reside in conditions of hypoxic as well as oxidative stress. HIF-1 and Nrf2 are two important transcription factors that play a crucial role in each of these conditions. While HIF-1 is important for cell survival under low oxygen conditions, Nrf2 provides 
cytoprotection against oxidative stress by upregulating antioxidants such as thioredoxin. Both HIF-1 and Nrf2 are induced in cells under intermittent hypoxia. This presents a possible link between the oxygen- and redox-dependent regulatory pathways. As described in 4.2, the increase in HIF-1 levels under intermittent hypoxia supersedes the HIF-1 levels observed in acute hypoxia. Similarly, higher thioredoxin levels were observed under intermittent hypoxia in comparison to acute hypoxia [68, 92]. Higher levels of other antioxidants have also been observed under intermittent hypoxia. For example, Prx1 was upregulated in response to hypoxia/reoxygenation, through the action of Nrf2, which binds to the ARE in the Prx1 promoter. In cells lacking Nrf2, Prx1 expression was compromised [89]. ROS levels are also higher under intermittent hypoxia [68] and are involved in both HIF-1 regulation and induction of antioxidant expression through the action of Nrf2. This may induce higher thioredoxin levels, which in turn results in the higher HIF-1 levels observed under intermittent hypoxia.

The high levels of both thioredoxin and HIF-1 in cancer cells cultured under intermittent hypoxia also have implications for tumor metastasis [79, 92]. Thioredoxin enhances the invasive behavior of tumor cells by regulating MMP activity, which is required for ECM degradation [25, 26]. HIF-1 over-expression during hypoxia has also been associated with ECM degradation by upregulating MMP-2 [94] and MMP-9 gene expression [95]. In a separate study, intermittent hypoxia treated A549 and H446 lung cancer cells exhibited increased invasion in comparison to normoxic cells. Down-regulation of the HIF-1 $\alpha$ gene decreased the cellular migration in these cells, thereby linking HIF-1 to cancer cell invasion under intermittent hypoxia [84]. Moreover, both thioredoxin and HIF-1 have been linked to the development of resistance against anticancer therapeutics [82, 96,97]. These common outcomes suggest an interplay of redox and hypoxic systems under intermittent hypoxia, with possible consequences for the design and testing of therapeutics.

\section{Consequences for drug development}

Development of resistance in cancer cells against chemotherapies presents a major setback in the prevention and cure of the disease that kills millions of people every year. Many chemotherapeutics are based on heavy metals, such as gold and platinum that generate ROS in cells, causing damage to DNA, proteins and lipids, and ultimately leading to apoptosis [98]. However, cells upregulate their antioxidant defenses in order to scavenge ROS, and as a result cancer cells become resistant to these drugs. High levels of thioredoxin and other antioxidant proteins in tumors are correlated with resistance to various chemotherapeutic agents, including cisplatin [97], docetaxel [96] and tamoxifen [99]. Furthermore, breast tumors with high levels of thioredoxin and other antioxidants prior to treatment with docetaxel were correlated with a high likelihood of developing resistance during therapy [100]. Therefore, anti-cancer therapies could be designed to inhibit the thioredoxin system in combination with radiation or chemotherapy.

Radiation treatment has been shown to cause reoxygenation of hypoxic tumors by increasing perfusion. As the better oxygenated cells die due to irradiation, the oxygen 
consumption decreases [101]. This has been linked with accumulation of ROS. Moeller and colleagues observed an elevation in levels of HIF-1 regulated proteins after 72 hours of radiation exposure [102]. Inhibition of ROS by a SOD mimetic prevented the stabilisation of HIF-1 $\alpha$ and sensitized the tumor to the damage caused by radiation [103]. In a separate study, they observed a delay in tumor growth following radiation when HIF-1 was inhibited using an antisense knockdown technique [104]. HIF-1 $\beta$ null tumor lines were also found to be sensitive to radiotherapy as they prevent the HIF-1 response [105]. All these studies suggest that radiation treatment causes an increase in ROS levels that stabilise HIF-1 $\alpha$ and leads to the subsequent increase in levels of HIF-1 mediated proteins.

The formation of stress granules has been observed in hypoxic tumors, which were found to disaggregate upon radiation exposure [102]. Stress granules contain mRNA transcripts and are formed in cells under stress. To save energy during stress, these transcripts are not translated into proteins [106]. Upon reoxygenation of hypoxic cells (during irradiation), the HIF-1 regulated transcripts are released and are translated, leading to an increase in VEGF and erythropoietin levels. This promotes angiogenesis, cell survival and proliferation, ultimately making the cells resistant to radiotherapy [102].

Cancer cells are often resistant not only to a single drug but develop cross-resistance against a range of drugs. Multidrug resistance (MDR) in cancer cells induces resistance against the efficacy of structurally and mechanistically different anticancer drugs, significantly decreasing their effectiveness. Higher drug doses in MDR cells not only produce toxic effects but also further stimulate the resistance, making tumors hard to treat [107]. MDR may arise due to alterations in targets, evasion of apoptosis, alteration in drug-uptake and transport of drugs out of cells [108]. The efflux of drugs from cells is mediated by transmembrane transporters belonging to the ATP-binding cassette (ABC) protein superfamily. These proteins use ATP to transport drugs out of cells [109]. One highly studied ABC transporter protein is P-glycoprotein (Pgp) (an MDR1 gene product) that has been linked to MDR in cancer cells [110]. High levels of Pgp are found in MDR cells and coincide with higher expression of HIF-1 [111-113]. Doublier and co-workers found MCF7 breast cancer cells grown under hypoxia to be resistant to doxorubicin. This resistance was associated with an increased Pgp expression via increased HIF-1 activation since transfection with siRNA specific to HIF-1 abolished this increase. They also observed that the binding of HIF-1 to the MDR1 gene promoter was higher in hypoxic cells. These cells accumulated lower levels of doxorubicin compared to normoxic cells [112]. Therefore, these roles of HIF-1 should be assessed during optimization of treatment strategies.

\section{Conclusion}

The oxygenation state of the cells has immense importance in cancer biology and both oxygen- and redox-dependent regulatory pathways are crucial for the process of carcinogenesis. While HIF-1 is important for tumor cells to adapt to hypoxia, thioredoxin protects cells from damage due to high oxygen levels. Since cancer cells have the ability to survive under conditions of both hypoxic and oxidative stress, one may expect a cross talk 
between the oxygen- and redox-dependent systems in tumors. This idea is further potentiated by the role of ROS in regulating the HIF-1 activity under both normoxia and hypoxia, and in inducing the thioredoxin system under oxidative stress.

The in vivo tumor environment is dynamic and cycles between low and high oxygen conditions. Surprisingly, these conditions are not taken into account while designing anticancer drugs. Most anticancer drugs are evaluated under normoxia (20\% oxygen), which is not physiologically relevant and does not reflect the actual in vivo tumor environment. Therefore, drugs tested under normoxic laboratory conditions may not respond similarly in the patient's body. Hence, it is important to evaluate the effectiveness of various chemotherapeutics under a wide range of oxygen conditions, particularly under intermittent hypoxia. Furthermore, both HIF-1 and thioredoxin levels are higher in cells grown under intermittent hypoxia. The higher levels of both these proteins have also been linked to enhanced invasion and resistance to treatment in cancer cells (Figure 10).

Therefore, the pathological implications of an upregulation of these important systems in cancer demonstrate the vital need to increase our understanding of the molecular mechanisms involved in the hypoxic and reoxygenation conditions encountered by the cancer cells in vivo, in order to design and test more effective therapeutics.

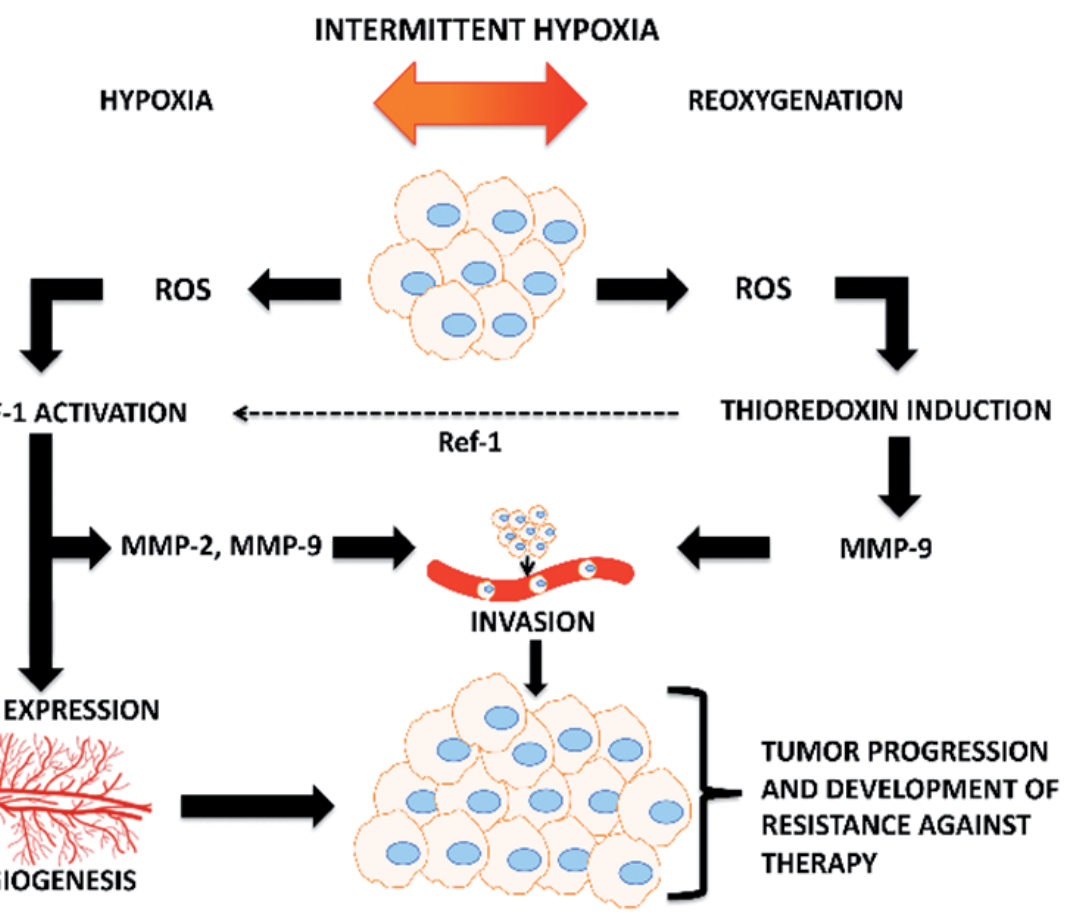

Figure 10. Overview of Trx and HIF-1 interaction under intermittent hypoxia and consequences for cancer progression. 


\section{Author details}

Maneet Bhatia, Therese C. Karlenius and Kathryn F. Tonissen*

School of Biomolecular and Physical Sciences, Griffith University, Nathan, Qld, Australia

Eskitis Institute for Cell and Molecular Therapies, Griffith University, Nathan, Qld, Australia

Giovanna Di Trapani

School of Biomolecular and Physical Sciences, Griffith University, Nathan, Qld, Australia

\section{Acknowledgement}

This research was supported by Griffith University Postgraduate Research Scholarships (to M.B. and T.K.), a Griffith University International Postgraduate Research Scholarship (to M.B.) and an Endeavour International Postgraduate Research Scholarship (to T.K.).

\section{References}

[1] Roy S, Khanna S, Bickerstaff AA, Subramanian SV, Atalay M, Bierl M, Pendyala S, Levy D, Sharma N, Venojarvi M, Strauch A, Orosz CG, Sen CK (2003) Oxygen sensing by primary cardiac fibroblasts: a key role of p21(Waf1/Cip1/Sdi1). Circ Res. 92: 264-271.

[2] Muniyappa H, Song S, Mathews CK, Das KC (2009) Reactive oxygen speciesindependent oxidation of thioredoxin in hypoxia: inactivation of ribonucleotide reductase and redox-mediated checkpoint control. J Biol Chem. 284: 17069-17081.

[3] Greer SN, Metcalf JL, Wang Y, Ohh M (2012) The updated biology of hypoxia-inducible factor. EMBO J. 31: 2448-2460.

[4] Dewhirst MW, Ong ET, Braun RD, Smith B, Klitzman B, Evans SM, Wilson D (1999) Quantification of longitudinal tissue pO2 gradients in window chamber tumours: impact on tumour hypoxia. Br. J. Cancer. 79: 1717-1722.

[5] Dewhirst MW, Kimura H, Rehmus SW, Braun RD, Papahadjopoulos D, Hong K, Secomb TW (1996) Microvascular studies on the origins of perfusion-limited hypoxia. Br. J. Cancer Suppl. 27: S247-251.

[6] Secomb TW, Hsu R, Dewhirst MW, Klitzman B, Gross JF (1993) Analysis of oxygen transport to tumor tissue by microvascular networks. Int. J. Radiat. Oncol. Biol. Phys. 25: 481-489.

[7] Lanzen J, Braun RD, Klitzman B, Brizel D, Secomb TW, Dewhirst MW (2006) Direct demonstration of instabilities in oxygen concentrations within the extravascular compartment of an experimental tumor. Cancer Res. 66: 2219-2223.

[8] Nehmeh SA, Lee NY, Schroder H, Squire O, Zanzonico PB, Erdi YE, Greco C, Mageras G, Pham HS, Larson SM, Ling CC, Humm JL (2008) Reproducibility of intratumor distribution of (18)F-fluoromisonidazole in head and neck cancer. Int. J. Radiat. Oncol. Biol. Phys. 70: 235-242.

\footnotetext{
" Corresponding Author
} 
[9] Dewhirst MW (2007) Intermittent hypoxia furthers the rationale for hypoxia-inducible factor-1 targeting. Cancer Res. 67: 854-855.

[10] Holmgren A (1985) Thioredoxin. Annu. Rev. Biochem. 54: 237-271.

[11] Das KC,Das CK (2000) Thioredoxin, a singlet oxygen quencher and hydroxyl radical scavenger: redox independent functions. Biochem Biophys Res Commun. 277: 443-447.

[12] Rhee SG, Chae HZ, Kim K (2005) Peroxiredoxins: a historical overview and speculative preview of novel mechanisms and emerging concepts in cell signaling. Free Radic. Biol. Med. 38: 1543-1552.

[13] Kim HY,Kim JR (2008) Thioredoxin as a reducing agent for mammalian methionine sulfoxide reductases B lacking resolving cysteine. Biochem Biophys Res Commun. 371: 490-494.

[14] Zhang C, Jia P, Jia Y, Weissbach H, Webster KA, Huang X, Lemanski SL, Achary M, Lemanski LF (2010) Methionine sulfoxide reductase A (MsrA) protects cultured mouse embryonic stem cells from H2O2-mediated oxidative stress. J Cell Biochem. 111: 94-103.

[15] Saitoh M, Nishitoh H, Fujii M, Takeda K, Tobiume K, Sawada Y, Kawabata M, Miyazono K, Ichijo H (1998) Mammalian thioredoxin is a direct inhibitor of apoptosis signal-regulating kinase (ASK) 1. EMBO J. 17: 2596-2606.

[16] Hirota K, Murata M, Sachi Y, Nakamura H, Takeuchi J, Mori K, Yodoi J (1999) Distinct roles of thioredoxin in the cytoplasm and in the nucleus. A two-step mechanism of redox regulation of transcription factor NF-kappaB. J. Biol. Chem. 274: 27891-27897.

[17] Xanthoudakis S,Curran T (1992) Identification and characterization of Ref-1, a nuclear protein that facilitates AP-1 DNA-binding activity. EMBO J. 11: 653-665.

[18] Abate C, Patel L, Rauscher FJ, 3rd, Curran T (1990) Redox regulation of fos and jun DNA-binding activity in vitro. Science. 249: 1157-1161.

[19] Rubartelli A, Bajetto A, Allavena G, Wollman E, Sitia R (1992) Secretion of thioredoxin by normal and neoplastic cells through a leaderless secretory pathway. J Biol Chem. 267: 24161-24164.

[20] Schwertassek U, Balmer Y, Gutscher M, Weingarten L, Preuss M, Engelhard J, Winkler M, Dick TP (2007) Selective redox regulation of cytokine receptor signaling by extracellular thioredoxin-1. EMBO J. 26: 3086-3097.

[21] Angelini G, Gardella S, Ardy M, Ciriolo MR, Filomeni G, Di Trapani G, Clarke F, Sitia R, Rubartelli A (2002) Antigen-presenting dendritic cells provide the reducing extracellular microenvironment required for T lymphocyte activation. Proceedings of the National Academy of Sciences of the United States of America. 99: 1491-1496.

[22] Backman E, Bergh AC, Lagerdahl I, Rydberg B, Sundstrom C, Tobin G, Rosenquist R, Linderholm M, Rosen A (2007) Thioredoxin, produced by stromal cells retrieved from the lymph node microenvironment, rescues chronic lymphocytic leukemia cells from apoptosis in vitro. Haematologica. 92: 1495-1504.

[23] Mougiakakos D, Johansson CC, Jitschin R, Bottcher M, Kiessling R (2011) Increased thioredoxin-1 production in human naturally occurring regulatory $\mathrm{T}$ cells confers enhanced tolerance to oxidative stress. Blood. 117: 857-861.

[24] Bertini R, Howard OM, Dong HF, Oppenheim JJ, Bizzarri C, Sergi R, Caselli G, Pagliei S, Romines B, Wilshire JA, Mengozzi M, Nakamura H, Yodoi J, Pekkari K, Gurunath R, 
Holmgren A, Herzenberg LA, Ghezzi P (1999) Thioredoxin, a redox enzyme released in infection and inflammation, is a unique chemoattractant for neutrophils, monocytes, and T cells. J. Exp. Med. 189: 1783-1789.

[25] Farina AR, Tacconelli A, Cappabianca L, Masciulli MP, Holmgren A, Beckett GJ, Gulino A, Mackay AR (2001) Thioredoxin alters the matrix metalloproteinase/tissue inhibitors of metalloproteinase balance and stimulates human SK-N-SH neuroblastoma cell invasion. Eur. J. Biochem. 268: 405-413.

[26] Farina AR, Cappabianca L, DeSantis G, Di Ianni N, Ruggeri P, Ragone M, Merolle S, Tonissen KF, Gulino A, Mackay AR (2011) Thioredoxin stimulates MMP-9 expression, de-regulates the MMP-9/TIMP-1 equilibrium and promotes MMP-9 dependent invasion in human MDA-MB-231 breast cancer cells. FEBS Lett. 585: 3328-3336.

[27] Lincoln DT, Ali Emadi EM, Tonissen KF, Clarke FM (2003) The thioredoxin-thioredoxin reductase system: over-expression in human cancer. Anticancer Res 23:2425-33

[28] Chaiswing L, Bourdeau-Heller JM, Zhong W, Oberley TD (2007) Characterization of redox state of two human prostate carcinoma cell lines with different degrees of aggressiveness. Free Radic Biol Med. 43: 202-215.

[29] Ceccarelli J, Delfino L, Zappia E, Castellani P, Borghi M, Ferrini S, Tosetti F, Rubartelli A (2008) The redox state of the lung cancer microenvironment depends on the levels of thioredoxin expressed by tumor cells and affects tumor progression and response to prooxidants. Int J Cancer. 123: 1770-1778.

[30] Sato H, Takino T, Okada Y, Cao J, Shinagawa A, Yamamoto E, Seiki M (1994) A matrix metalloproteinase expressed on the surface of invasive tumour cells. Nature. 370: 61-65.

[31] Nagase H (1997) Activation mechanisms of matrix metalloproteinases. Biol Chem. 378: 151-160.

[32] Rushmore TH, Morton MR, Pickett CB (1991) The antioxidant responsive element. Activation by oxidative stress and identification of the DNA consensus sequence required for functional activity. J Biol Chem. 266: 11632-11639.

[33] Ishii T, Itoh K, Takahashi S, Sato H, Yanagawa T, Katoh Y, Bannai S, Yamamoto M (2000) Transcription factor Nrf2 coordinately regulates a group of oxidative stressinducible genes in macrophages. J. Biol. Chem. 275: 16023-16029.

[34] Itoh K, Wakabayashi N, Katoh Y, Ishii T, Igarashi K, Engel JD, Yamamoto M (1999) Keap1 represses nuclear activation of antioxidant responsive elements by Nrf2 through binding to the amino-terminal Neh2 domain. Genes Dev. 13: 76-86.

[35] Zhang DD,Hannink M (2003) Distinct cysteine residues in Keap1 are required for Keap1-dependent ubiquitination of $\mathrm{Nrf2}$ and for stabilization of Nrf2 by chemopreventive agents and oxidative stress. Mol Cell Biol. 23: 8137-8151.

[36] Itoh K, Chiba T, Takahashi S, Ishii T, Igarashi K, Katoh Y, Oyake T, Hayashi N, Satoh K, Hatayama I, Yamamoto M, Nabeshima Y (1997) An Nrf2/small Maf heterodimer mediates the induction of phase II detoxifying enzyme genes through antioxidant response elements. Biochem Biophys Res Commun. 236: 313-322.

[37] Kim YC, Masutani H, Yamaguchi Y, Itoh K, Yamamoto M, Yodoi J (2001) Hemininduced activation of the thioredoxin gene by Nrf2. A differential regulation of the 
antioxidant responsive element by a switch of its binding factors. J. Biol. Chem. 276: 18399-18406.

[38] Hintze KJ, Wald KA, Zeng H, Jeffery EH, Finley JW (2003) Thioredoxin reductase in human hepatoma cells is transcriptionally regulated by sulforaphane and other electrophiles via an antioxidant response element. J. Nutr. 133: 2721-2727.

[39] Salceda S,Caro J (1997) Hypoxia-inducible factor 1alpha (HIF-1alpha) protein is rapidly degraded by the ubiquitin-proteasome system under normoxic conditions. Its stabilization by hypoxia depends on redox-induced changes. J Biol Chem. 272: 22642-47.

[40] Huang ZJ, Edery I, Rosbash M (1993) PAS is a dimerization domain common to Drosophila period and several transcription factors. Nature. 364: 259-262.

[41] Qin C, Wilson C, Blancher C, Taylor M, Safe S, Harris AL (2001) Association of ARNT splice variants with estrogen receptor-negative breast cancer, poor induction of vascular endothelial growth factor under hypoxia, and poor prognosis. Clin Cancer Res. 7: 818823.

[42] Mole DR, Blancher C, Copley RR, Pollard PJ, Gleadle JM, Ragoussis J, Ratcliffe PJ (2009) Genome-wide association of hypoxia-inducible factor (HIF)-1alpha and HIF-2alpha DNA binding with expression profiling of hypoxia-inducible transcripts. J Biol Chem. 284: 16767-16775.

[43] Wiesener MS, Jurgensen JS, Rosenberger C, Scholze CK, Horstrup JH, Warnecke C, Mandriota S, Bechmann I, Frei UA, Pugh CW, Ratcliffe PJ, Bachmann S, Maxwell PH, Eckardt KU (2003) Widespread hypoxia-inducible expression of HIF-2alpha in distinct cell populations of different organs. FASEB J. 17: 271-273.

[44] Loboda A, Jozkowicz A, Dulak J (2010) HIF-1 and HIF-2 transcription factors--similar but not identical. Mol Cells. 29: 435-442.

[45] Hu CJ, Wang LY, Chodosh LA, Keith B, Simon MC (2003) Differential roles of hypoxiainducible factor 1alpha (HIF-1alpha) and HIF-2alpha in hypoxic gene regulation. Mol Cell Biol. 23: 9361-9374.

[46] van Patot MC,Gassmann M (2011) Hypoxia: adapting to high altitude by mutating EPAS-1, the gene encoding HIF-2alpha. High Alt Med Biol. 12: 157-167.

[47] Bracken CP, Fedele AO, Linke S, Balrak W, Lisy K, Whitelaw ML, Peet DJ (2006) Cellspecific regulation of hypoxia-inducible factor (HIF)-1alpha and HIF-2alpha stabilization and transactivation in a graded oxygen environment. J Biol Chem. 281: 22575-22585.

[48] Imamura T, Kikuchi H, Herraiz MT, Park DY, Mizukami Y, Mino-Kenduson M, Lynch MP, Rueda BR, Benita Y, Xavier RJ, Chung DC (2009) HIF-1alpha and HIF-2alpha have divergent roles in colon cancer. Int J Cancer. 124: 763-771.

[49] Makino Y, Cao R, Svensson K, Bertilsson G, Asman M, Tanaka H, Cao Y, Berkenstam A, Poellinger L (2001) Inhibitory PAS domain protein is a negative regulator of hypoxiainducible gene expression. Nature. 414: 550-554.

[50] Pugh CW, O'Rourke JF, Nagao M, Gleadle JM, Ratcliffe PJ (1997) Activation of hypoxiainducible factor-1; definition of regulatory domains within the alpha subunit. J Biol Chem. 272: 11205-11214. 
[51] Jiang BH, Zheng JZ, Leung SW, Roe R, Semenza GL (1997) Transactivation and inhibitory domains of hypoxia-inducible factor 1alpha. Modulation of transcriptional activity by oxygen tension. J Biol Chem. 272: 19253-19260.

[52] Kallio PJ, Okamoto K, O'Brien S, Carrero P, Makino Y, Tanaka H, Poellinger L (1998) Signal transduction in hypoxic cells: inducible nuclear translocation and recruitment of the CBP/p300 coactivator by the hypoxia-inducible factor-1alpha. EMBO J. 17: 65736586.

[53] Ema M, Hirota K, Mimura J, Abe H, Yodoi J, Sogawa K, Poellinger L, Fujii-Kuriyama Y (1999) Molecular mechanisms of transcription activation by HLF and HIF1alpha in response to hypoxia: their stabilization and redox signal-induced interaction with CBP/p300. EMBO J. 18: 1905-1914.

[54] Lando D, Peet DJ, Whelan DA, Gorman JJ, Whitelaw ML (2002) Asparagine hydroxylation of the HIF transactivation domain a hypoxic switch. Science. 295: 858861.

[55] Pouyssegur J, Dayan F, Mazure NM (2006) Hypoxia signalling in cancer and approaches to enforce tumour regression. Nature. 441: 437-443.

[56] Bruick RK,McKnight SL (2001) A conserved family of prolyl-4-hydroxylases that modify HIF. Science. 294: 1337-1340.

[57] Maxwell PH, Wiesener MS, Chang GW, Clifford SC, Vaux EC, Cockman ME, Wykoff CC, Pugh CW, Maher ER, Ratcliffe PJ (1999) The tumour suppressor protein VHL targets hypoxia-inducible factors for oxygen-dependent proteolysis. Nature. 399: 271275.

[58] Jaakkola P, Mole DR, Tian YM, Wilson MI, Gielbert J, Gaskell SJ, Kriegsheim A, Hebestreit HF, Mukherji M, Schofield CJ, Maxwell PH, Pugh CW, Ratcliffe PJ (2001) Targeting of HIF-alpha to the von Hippel-Lindau ubiquitylation complex by O2regulated prolyl hydroxylation. Science. 292: 468-472.

[59] Huang J, Zhao Q, Mooney SM, Lee FS (2002) Sequence determinants in hypoxiainducible factor-1alpha for hydroxylation by the prolyl hydroxylases PHD1, PHD2, and PHD3. J Biol Chem. 277: 39792-39800.

[60] Cockman ME, Masson N, Mole DR, Jaakkola P, Chang GW, Clifford SC, Maher ER, Pugh CW, Ratcliffe PJ, Maxwell PH (2000) Hypoxia inducible factor-alpha binding and ubiquitylation by the von Hippel-Lindau tumor suppressor protein. J Biol Chem. 275: 25733-25741.

[61] Lando D, Peet DJ, Gorman JJ, Whelan DA, Whitelaw ML, Bruick RK (2002) FIH-1 is an asparaginyl hydroxylase enzyme that regulates the transcriptional activity of hypoxiainducible factor. Genes Dev. 16: 1466-1471.

[62] Chandel NS, McClintock DS, Feliciano CE, Wood TM, Melendez JA, Rodriguez AM, Schumacker PT (2000) Reactive oxygen species generated at mitochondrial complex III stabilize hypoxia-inducible factor-1alpha during hypoxia: a mechanism of $\mathrm{O} 2$ sensing. J. Biol. Chem. 275: 25130-25138.

[63] Li F, Sonveaux P, Rabbani ZN, Liu S, Yan B, Huang Q, Vujaskovic Z, Dewhirst MW, Li CY (2007) Regulation of HIF-1alpha stability through S-nitrosylation. Mol. Cell. 26: 6374 . 
[64] Mansfield KD, Guzy RD, Pan Y, Young RM, Cash TP, Schumacker PT, Simon MC (2005) Mitochondrial dysfunction resulting from loss of cytochrome c impairs cellular oxygen sensing and hypoxic HIF-alpha activation. Cell. Metab. 1: 393-399.

[65] Pan Y, Mansfield KD, Bertozzi CC, Rudenko V, Chan DA, Giaccia AJ, Simon MC (2007) Multiple factors affecting cellular redox status and energy metabolism modulate hypoxia-inducible factor prolyl hydroxylase activity in vivo and in vitro. Mol Cell Biol. 27: 912-925.

[66] Hohler B, Lange B, Holzapfel B, Goldenberg A, Hanze J, Sell A, Testan H, Moller W, Kummer W (1999) Hypoxic upregulation of tyrosine hydroxylase gene expression is paralleled, but not induced, by increased generation of reactive oxygen species in PC12 cells. FEBS letters. 457: 53-56.

[67] Kolamunne RT, Clare M, Griffiths HR (2011) Mitochondrial superoxide anion radicals mediate induction of apoptosis in cardiac myoblasts exposed to chronic hypoxia. Archives of biochemistry and biophysics. 505: 256-265.

[68] Karlenius TC, Shah F, Di Trapani G, Clarke FM, Tonissen KF (2012) Cycling hypoxia up-regulates thioredoxin levels in human MDA-MB-231 breast cancer cells. Biochem Biophys Res Commun. 419: 350-355.

[69] Michelakis ED, Hampl V, Nsair A, Wu X, Harry G, Haromy A, Gurtu R, Archer SL (2002) Diversity in mitochondrial function explains differences in vascular oxygen sensing. Circ Res. 90: 1307-1315.

[70] Paky A, Michael JR, Burke-Wolin TM, Wolin MS, Gurtner GH (1993) Endogenous production of superoxide by rabbit lungs: effects of hypoxia or metabolic inhibitors. Journal of applied physiology. 74: 2868-2874.

[71] Welsh SJ, Bellamy WT, Briehl MM, Powis G (2002) The redox protein thioredoxin-1 (Trx-1) increases hypoxia-inducible factor 1alpha protein expression: Trx-1 overexpression results in increased vascular endothelial growth factor production and enhanced tumor angiogenesis. Cancer Res. 62: 5089-5095.

[72] Jones DT, Pugh CW, Wigfield S, Stevens MF, Harris AL (2006) Novel thioredoxin inhibitors paradoxically increase hypoxia-inducible factor-alpha expression but decrease functional transcriptional activity, DNA binding, and degradation. Clin Cancer Res. 12: 5384-5394.

[73] Csiki I, Yanagisawa K, Haruki N, Nadaf S, Morrow JD, Johnson DH, Carbone DP (2006) Thioredoxin-1 modulates transcription of cyclooxygenase-2 via hypoxia-inducible factor-1alpha in non-small cell lung cancer. Cancer Res. 66: 143-150.

[74] Welsh SJ, Williams RR, Birmingham A, Newman DJ, Kirkpatrick DL, Powis G (2003) The thioredoxin redox inhibitors 1-methylpropyl 2-imidazolyl disulfide and pleurotin inhibit hypoxia-induced factor 1alpha and vascular endothelial growth factor formation. Mol Cancer Ther. 2: 235-243.

[75] Naranjo-Suarez S, Carlson BA, Tsuji PA, Yoo MH, Gladyshev VN, Hatfield DL (2012) HIF-Independent Regulation of Thioredoxin Reductase 1 Contributes to the High Levels of Reactive Oxygen Species Induced by Hypoxia. PLoS One. 7: e30470. 
[76] Beutler E, Blume KG, Kaplan JC, Lohr GW, Ramot B, Valentine WN (1977) International Committee for Standardization in Haematology: recommended methods for red-cell enzyme analysis. Br J Haematol. 35: 331-340.

[77] Li DL, Liu JJ, Liu BH, Hu H, Sun L, Miao Y, Xu HF, Yu XJ, Ma X, Ren J, Zang WJ (2011) Acetylcholine inhibits hypoxia-induced tumor necrosis factor-alpha production via regulation of MAPKs phosphorylation in cardiomyocytes. J Cell Physiol. 226: 1052-1059.

[78] Park KJ, Kim YJ, Choi EJ, Park NK, Kim GH, Kim SM, Lee SY, Bae JW, Hwang KK, Kim DW, Cho MC (2010) Expression pattern of the thioredoxin system in human endothelial progenitor cells and endothelial cells under hypoxic injury. Korean Circ. J. 40: 651-658.

[79] Semenza GL,Prabhakar NR (2007) HIF-1-dependent respiratory, cardiovascular, and redox responses to chronic intermittent hypoxia. Antioxid. Redox Signal. 9: 1391-1396.

[80] Yuan G, Nanduri J, Bhasker CR, Semenza GL, Prabhakar NR (2005) Ca2+/calmodulin kinase-dependent activation of hypoxia inducible factor 1 transcriptional activity in cells subjected to intermittent hypoxia. J. Biol. Chem. 280: 4321-4328.

[81] Yao K, Gietema JA, Shida S, Selvakumaran M, Fonrose X, Haas NB, Testa J, O'Dwyer PJ (2005) In vitro hypoxia-conditioned colon cancer cell lines derived from HCT116 and HT29 exhibit altered apoptosis susceptibility and a more angiogenic profile in vivo. Br J Cancer. 93: 1356-1363.

[82] Martinive P, Defresne F, Bouzin C, Saliez J, Lair F, Gregoire V, Michiels C, Dessy C, Feron $O$ (2006) Preconditioning of the tumor vasculature and tumor cells by intermittent hypoxia: implications for anticancer therapies. Cancer Res. 66: 11736-11744.

[83] Cairns RA, Kalliomaki T, Hill RP (2001) Acute (cyclic) hypoxia enhances spontaneous metastasis of KHT murine tumors. Cancer Res. 61: 8903-8908.

[84] Liu Y, Song X, Wang X, Wei L, Liu X, Yuan S, Lv L (2010) Effect of chronic intermittent hypoxia on biological behavior and hypoxia-associated gene expression in lung cancer cells. J Cell Biochem. 111: 554-563.

[85] Nanduri J, Wang N, Yuan G, Khan SA, Souvannakitti D, Peng YJ, Kumar GK, Garcia JA, Prabhakar NR (2009) Intermittent hypoxia degrades HIF-2alpha via calpains resulting in oxidative stress: implications for recurrent apnea-induced morbidities. Proc Natl Acad Sci U S A. 106: 1199-1204.

[86] Peng YJ, Overholt JL, Kline D, Kumar GK, Prabhakar NR (2003) Induction of sensory long-term facilitation in the carotid body by intermittent hypoxia: implications for recurrent apneas. Proc Natl Acad Sci U S A. 100: 10073-10078.

[87] Hedley D, Pintilie M, Woo J, Nicklee T, Morrison A, Birle D, Fyles A, Milosevic M, Hill $\mathrm{R}$ (2004) Up-regulation of the redox mediators thioredoxin and apurinic/apyrimidinic excision (APE)/Ref-1 in hypoxic microregions of invasive cervical carcinomas, mapped using multispectral, wide-field fluorescence image analysis. Am. J. Pathol. 164: 557-565.

[88] Kim HJ, Chae HZ, Kim YJ, Kim YH, Hwangs TS, Park EM, Park YM (2003) Preferential elevation of Prx I and Trx expression in lung cancer cells following hypoxia and in human lung cancer tissues. Cell. Biol. Toxicol. 19: 285-298.

[89] Kim YJ, Ahn JY, Liang P, Ip C, Zhang Y, Park YM (2007) Human prx1 gene is a target of Nrf2 and is up-regulated by hypoxia/reoxygenation: implication to tumor biology. Cancer Res. 67: 546-554. 
[90] Jewell UR, Kvietikova I, Scheid A, Bauer C, Wenger RH, Gassmann M (2001) Induction of HIF-1alpha in response to hypoxia is instantaneous. FASEB J. 15: 1312-1314.

[91] Kim SM, Kim JY, Lee S, Park JH (2010) Adrenomedullin protects against hypoxia/reoxygenation-induced cell death by suppression of reactive oxygen species via thiol redox systems. FEBS Lett. 584: 213-218.

[92] Malec V, Gottschald OR, Li S, Rose F, Seeger W, Hanze J (2010) HIF-1 alpha signaling is augmented during intermittent hypoxia by induction of the Nrf2 pathway in NOX1expressing adenocarcinoma A549 cells. Free Radic Biol Med. 48: 1626-1635.

[93] Turoczi T, Chang VW, Engelman RM, Maulik N, Ho YS, Das DK (2003) Thioredoxin redox signaling in the ischemic heart: an insight with transgenic mice overexpressing Trx1. J. Mol. Cell. Cardiol. 35: 695-704.

[94] Krishnamachary B, Berg-Dixon S, Kelly B, Agani F, Feldser D, Ferreira G, Iyer N, LaRusch J, Pak B, Taghavi P, Semenza GL (2003) Regulation of colon carcinoma cell invasion by hypoxia-inducible factor 1. Cancer Res. 63: 1138-1143.

[95] Choi JY, Jang YS, Min SY, Song JY (2011) Overexpression of MMP-9 and HIF-1alpha in Breast Cancer Cells under Hypoxic Conditions. J Breast Cancer. 14: 88-95.

[96] Kim SJ, Miyoshi Y, Taguchi T, Tamaki Y, Nakamura H, Yodoi J, Kato K, Noguchi S (2005) High thioredoxin expression is associated with resistance to docetaxel in primary breast cancer. Clin. Cancer Res. 11: 8425-8430.

[97] Sasada T, Iwata S, Sato N, Kitaoka Y, Hirota K, Nakamura K, Nishiyama A, Taniguchi Y, Takabayashi A, Yodoi J (1996) Redox control of resistance to cisdiamminedichloroplatinum (II) (CDDP): protective effect of human thioredoxin against CDDP-induced cytotoxicity. J. Clin. Invest. 97: 2268-2276.

[98] Desoize B (2002) Cancer and metals and metal compounds: part I--carcinogenesis. Crit Rev Oncol Hematol. 42: 1-3.

[99] Schiff R, Reddy P, Ahotupa M, Coronado-Heinsohn E, Grim M, Hilsenbeck SG, Lawrence R, Deneke S, Herrera R, Chamness GC, Fuqua SA, Brown PH, Osborne CK (2000) Oxidative stress and AP-1 activity in tamoxifen-resistant breast tumors in vivo. J Natl Cancer Inst. 92: 1926-1934.

[100] Iwao-Koizumi K, Matoba R, Ueno N, Kim SJ, Ando A, Miyoshi Y, Maeda E, Noguchi S, Kato K (2005) Prediction of docetaxel response in human breast cancer by gene expression profiling. J. Clin. Oncol. 23: 422-431.

[101] Bussink J, Kaanders JH, Rijken PF, Raleigh JA, Van der Kogel AJ (2000) Changes in blood perfusion and hypoxia after irradiation of a human squamous cell carcinoma xenograft tumor line. Radiat Res. 153: 398-404.

[102] Moeller BJ, Cao Y, Li CY, Dewhirst MW (2004) Radiation activates HIF-1 to regulate vascular radiosensitivity in tumors: role of reoxygenation, free radicals, and stress granules. Cancer Cell. 5: 429-441.

[103] Moeller BJ, Batinic-Haberle I, Spasojevic I, Rabbani ZN, Anscher MS, Vujaskovic Z, Dewhirst MW (2005) A manganese porphyrin superoxide dismutase mimetic enhances tumor radioresponsiveness. Int J Radiat Oncol Biol Phys. 63: 545-552.

[104] Moeller BJ, Dreher MR, Rabbani ZN, Schroeder T, Cao Y, Li CY, Dewhirst MW (2005) Pleiotropic effects of HIF-1 blockade on tumor radiosensitivity. Cancer Cell. 8: 99-110. 
[105] Williams KJ, Telfer BA, Xenaki D, Sheridan MR, Desbaillets I, Peters HJ, Honess D, Harris AL, Dachs GU, van der Kogel A, Stratford IJ (2005) Enhanced response to radiotherapy in tumours deficient in the function of hypoxia-inducible factor-1. Radiother Oncol. 75: 89-98.

[106] Kedersha NL, Gupta M, Li W, Miller I, Anderson P (1999) RNA-binding proteins TIA1 and TIAR link the phosphorylation of eIF-2 alpha to the assembly of mammalian stress granules. J Cell Biol. 147: 1431-1442.

[107] Ozben T (2006) Mechanisms and strategies to overcome multiple drug resistance in cancer. FEBS Lett. 580: 2903-2909.

[108] Gottesman MM, Fojo T, Bates SE (2002) Multidrug resistance in cancer: role of ATPdependent transporters. Nat Rev Cancer. 2: 48-58.

[109] Sarkadi B, Homolya L, Szakacs G, Varadi A (2006) Human multidrug resistance ABCB and $A B C G$ transporters: participation in a chemoimmunity defense system. Physiol Rev. 86: 1179-1236.

[110] Tiwari AK, Sodani K, Dai CL, Ashby CR, Jr., Chen ZS (2011) Revisiting the ABCs of multidrug resistance in cancer chemotherapy. Curr Pharm Biotechnol. 12: 570-594.

[111] Comerford KM, Wallace TJ, Karhausen J, Louis NA, Montalto MC, Colgan SP (2002) Hypoxia-inducible factor-1-dependent regulation of the multidrug resistance (MDR1) gene. Cancer Res. 62: 3387-3394.

[112] Doublier S, Belisario DC, Polimeni M, Annaratone L, Riganti C, Allia E, Ghigo D, Bosia A, Sapino A (2012) HIF-1 activation induces doxorubicin resistance in MCF7 3-D spheroids via P-glycoprotein expression: a potential model of the chemo-resistance of invasive micropapillary carcinoma of the breast. BMC Cancer. 12: 4.

[113] Riganti C, Doublier S, Viarisio D, Miraglia E, Pescarmona G, Ghigo D, Bosia A (2009) Artemisinin induces doxorubicin resistance in human colon cancer cells via calciumdependent activation of HIF-1alpha and P-glycoprotein overexpression. Br J Pharmacol. 156: 1054-1066. 